\title{
EVALUASI PELAKSANAAN PROGRAM NASIONAL AGRARIA DAN PENDAFTARAN TANAH SISTEMATIS LENGKAP DALAM PEMBANGUNAN WILAYAH DESA KINABUHUTAN, KECAMATAN LIKUPANG BARAT, KABUPATEN MINAHASA UTARA
}

\author{
Sherley Veralin Kamurahan \\ Bobby J. V. Polii \\ Charles R. Ngangi
}

\begin{abstract}
This study aims to evaluate the implementation of : (1) the national agrarian program certification (PRONA), and (2) complete systematic land registration (PTSL). The research used descriptive qualitative approach. This research was conducted in Kinabuhutan Village, West Likupang Sub-district, North Minahasa District, North Sulawesi Province, that conducted from June 2017 to January 2018. The sample consisted of 23 respondents for PRONA and 21 respondents for PTSL. Sample determination was done by using purposive sampling technique. Data collection methods used are Observation, Interview and Documentation. Data analysis technique used was descriptive qualitative. The results showed that: (1) Implementation of land certification through PRONA program has been run in accordance with the stages of activities determined according to regulations. However, there are problems in the implementation of: (i) proof of ownership (ownership rights) whether in the form of ownership based on sale and purchase or grant or inheritance, (ii) land tenure status as cultivator causing not knowing land history from first holder right until last owner and sign the upper limit of their land which is the main requirement in the management of the certificate. (2) The implementation of a Complete Systematic Soil System (PTSL) program is in accordance with the stages regulated. There are, however, shortcomings in which members of the community who have selected to participate in the PTSL program cannot show evidence for to proof of ownership, at the time of measurement there are not available at the site, and there is also no way of indicating the boundaries of the land because it has no boundary markers. The problem encountered in the implementation of both programs is the limited number of off icers who have the competence as land measurement officers.
\end{abstract}

Keywords: Evaluation, PRONA, PTSL, Kinabuhutan Village, North Minahasa Regency

\begin{abstract}
ABSTRAK
Penelitian ini bertujuan untuk mengevaluasi: (1) pelaksanaan sertipikasi program nasional agraria (PRONA), dan (2) pendaftaran tanah sistematis lengkap (PTSL) dalam pembangunan wilayah Desa Kinabuhutan, Kecamatan Likupang Barat, Kabupaten Minahasa Utara. Penelitian ini menggunakan pendekatan kualitatif deskriptif. Penelitian ini dilaksanakan di Desa Kinabuhutan Kecamatan Likupang Barat Kabupaten Minahasa Utara Propinsi Sulawesi Utara yang dilaksanakan pada bulan Juni Tahun 2017 sampai dengan bulan Januari 2018. Sampel penelitian terdiri dari 23 responden untuk PRONA dan 21 responden untuk PTSL. Penentuan sampel dilakukan dengan menggunakan teknik purposive sampling. Metode pengumpulan data yang digunakan adalah Observasi, Wawancara dan Dokumentasi. Teknik analisis data yang digunakan dalam penelitian ini adalah deskriptif kualitatif. Hasil penelitian menunjukkan bahwa: (1) Pelaksanaan pensertipikatan tanah melalui program PRONA sudah berjalan sesuai dengan tahapan kegiatan yang ditentukan sesuai peraturan. Namun terdapat masalah dalam pelaksanaannya berupa: (i) bukti kepemilikan (alas hak) baik berupa kepemilikan berdasarkan jual beli atau hibah atau warisan, (ii) status penguasaan tanah sebagai penggarap menyebabkan tidak mengetahui riwayat tanah dari pemegang hak pertama sampai pemilik terakhir dan tanda tanda batas atas tanah mereka yang menjadi syarat utama dalam kepengurusan sertipikat. (2) Pelaksanaan program pengsertipikatan tanah sistimatis Lengkap (PTSL) sudah sesuai dengan tahapan yang diatur. Namun terdapat kekurangan-kekurangan dimana anggota masyarakat yang terpilih sebagai peserta program PTSL tidak memiliki bukti kepemilikan, pada saat pengukuran ada yang tidak berada ditempat, dan ada juga tidak dapat menunjukkan batas-batas tanah karena tidak memiliki penanda batas. Masalah yang ditemui dalam pelaksanaan kedua program adalah terbatasnya jumlah petugas yang memiliki kompetensi sebagai petugas pengukur tanah.
\end{abstract}

Kata kunci: Evaluasi, PRONA, PTSL, Desa Kinabuhutan, Kabupaten Minahasa Utara 


\section{PENDAHULUAN}

\section{Latar Belakang}

Pembangunan nasional secara berkesinambungan untuk tujuan nasional sebagaimana dilaksanakan mewujudkan diamanatkan dalam Undang-Undang Dasar 1945 alinea 4 yang berbunyi:

Melindungi segenap bangsa Indonesia dan seluruh tumpah darah Indonesia dan untuk memajukan kesejahteraan umum mencerdaskan kehidupan bangsa, dan ikut melaksanakan ketertiban dunia yang berdasarkan kemerdekaan, perdamaian abadi dan keadilan sosial.

$\begin{array}{lrrr} & \text { Pembangunan merupakan salah } & \text { satu } \\ \text { kunci keberhasilan suatu negara } & \text { untuk } \\ \text { mewujudkan kesejahteraan } & \text { rakyat } & \text { dan }\end{array}$ memenuhi seluruh kebutuhan masyarakat. Hal tersebut dikarenakan pembangunan merupakan proses menuju perubahan, perkembangan dari suatu kesulitan menuju ke arah kemudahan (Harnindi S. 2014). Menurut undang-undang Republik Indonesia Nomor 25 Tahun 2004 Tentang Sistem Perencanaan Pembangunan Nasional, adalah: "Program instrumen kebijakan yang berisi satu atau lebih kegiatan yang dilaksanakan oleh instansi pemerintah/lembaga untuk mencapai sasaran dan tujuan serta memperoleh alokasi anggaran atau kegiatan masyarakat yang dikoordinasikan oleh instansi masyarakat."

Dalam konteks pelaksanaan pembangunan daerah, sesuai dengan peran pemerintah daerah dalam era otonomi luas, perencanaan pembangunan daerah diperlukan karena pelaksanaan pembangunan didesentralisasikan dari pemerintah pusat kepada pemerintah daerah. Bratakusumah (2004) mengatakan perencanaan pembangunan merupakan suatu tahapan awal dalam proses pembangunan. Sebagai tahapan awal, perencanaan pembangunan menjadi bahan/ pedoman/ acuan dasar bagi pelaksanaan kegiatan pembangunan (action plan).

Dalam hubungannya dengan suatu daerah sebagai area (wilayah) pembangunan dimana terbentuk konsep perencanaan pembagunan daerah (Bratakusumah, 2004) dapat dinyatakan bahwa perencanaan pembangunan daerah adalah suatu proses perencanaan yang dimaksudkan untuk melakukan perubahan menuju arah yang lebih baik bagi suatu komunitas masyarakat, pemerintah dan lingkungannya dalam wilayah/daerah tertentu dengan memanfaatkan atau mendayagunakan berbagai sumber daya yang ada dan harus memilki orientasi yang bersifat menyeluruh, lengkap, tetapi tetap berpegang pada azas prioritas. Dengan demikian, Perencanaan Pembangunan Daerah (PPD) akan membentuk tiga hal pokok yang meliputi: perencanaan komunitas, menyangkut suatu area (daerah), dan sumber daya yang ada di dalamya. Pentingnya orientasi holisti dalam perencanaan pembangunan daerah, karena dengan tingkat kompleksitas yang besar tidak mungkin kita mengabaikan masalah-masalah yang muncul sebagai tuntutan kebutuhan sosial yang tak terelakkan. Tetapi dipihak lain adanya keterbatasan sumberdaya yang dimiliki tidak memungkinkan pula untuk melakukan proses pembangunan yang langsung menyentuh atau mengatasi seluruh permasalahan dan tuntutan secara sekaligus. Dalam hal inilah penentuan prioritas perlu dilakukan, yang dalam prakteknya dilakukan melalui proses perencanaan.

Melakukan perencanaan pembangunan daerah berbeda dengan melakukan perencanaan proyek atau perencanaan-perencanaan kegiatan yang bersifat lebih spesifik dan mikro. Proses perencanaan pembangunan daerah jauh lebih kompleks dan rumit, karena menyangkut perencanaan pembangunan bagi suatu wilayah dengan berbagai komunitas, lingkungan dan kondisi sosial yang ada didalamnya. Apalagi bila mencakup wilayah pembangunan yang luas, kultur sosialnya amat heterogen, dengan tingkat kepentingan yang berbeda.

Undang-Undang Dasar 1945, telah menegaskan bahwa Negara Indonesia merupakan Negara yang berdasarkan atas hukum (rechstaat) dan tidak berdasarkan atas kekuasaan belaka (machstaat). Demikian pula soal tanah, pemerintah berkewajiban memberikan kepastian hukum terhadap status tanah yang dikuasai masyarakat atau badan usaha. Negara Indonesia telah menjamin hak rakyatnya. Sebagai negara yang demokratis 
berdasarkan Pancasila dan Undang-Undang Dasar 1945, serta menjunjung tinggi hak asasi manusia dan menjamin segala warga negara bersamaan kedudukannya di dalam hukum dan pemerintahannya dengan tidak terkecuali (Harsono B, 2008;14).

Sebagai bagian dari upaya mencapai pembangunan yang berkeadilan dan berkelanjutan, serta menekan kesenjangan sosial ekonomi, dan mencegah maraknya sengketa hak atas tanah diseluruh Indonesia, Kementrian Agraria dan Tata Ruang Badan Pertanahan Nasional atau Kentrian ATR BPN melakukan langkah strategis yang meliputi legalisasi dan redistribusi aset tanah serat penaatan ruang yang berkelanjutan dan terus menerus melakukan peningkatan pelayanan. Pemerintah menargetkan dalam 2017 telah tersertifikat 5.000 .000 bidang tanah, dengan demikian pada tahun 2018 kepemilikian tanah bersertifikat bisa bertambah menjadi

53.000.000 bidang yang bertujuan agar ada kepastian hukum, sehingga dimasa mendatang konflik tanah itu akan bisa dihindari dan akan membantu tata ruang (Kementrian ATR BPN, 2017).

Tanah merupakan tempat berpijak manusia dalam menjalankan kodratnya sebagai mahluk pribadi maupun sosial. Kepemilikan tanah haruslah jelas yang dibuktikan dengan sebuah sertifikat kepemilikan tanah yang sah secara hukum yang disebut sertifikat tanah. Sertifikat tanah sangat diperlukan dalam rangka tertib administrasi pertanahan. Untuk meningkatkan pelayanan kepada masyarakat dalam pensertifikatan tanah dan dalam rangka mendekatkan pelaksanaan tugas dan fungsi. Sejalan dengan tekad dan kebijaksanaan pemerintah untuk melaksanakan pembangunan dalam rangka mencapai tujuan nasional, aspek pertanahan merupakan salah satu faktor penunjang yang sangat penting bagi keberhasilan dan pemerataan hasil pembangunan. Dikatakan penting, karena tanah menjadi kebutuhan yang sangat menentukan bagi hajat hidup manusia (Harsono, 2003).

Menurut Kepala Seksi Penataan Pertanahan Teddy Massie "Berbagai alasan menjadi penyebab lahan bodong diantaranya tingkat kesadaran masyarakat yang kecil terhadap kepemilikan sertipikat mereka rata-rata merasa cukup dengan sertipikat jual beli atau keterangan dari kelurahan maupun desa. Nanti sudah terjadi sengketa baru mulai kocar-kacir" (Manado post, 22 Mei 2018).

Kepastian hukum penting untuk mengatur kehidupan masyarakat adil, dapat menghindarkan pelanggaran yang dapat dilakukan oleh masyarakat ataupun penegak hukum itu sendiri. Untuk itu diperlukan adanya kaidah hukum yang dapat dipergunakan negara dalam mengatur tatanan kehidupan masyarakat. Demikian pula mengenai lahan, UndangUndang Republik Indonesia Nomor 5 Tahun 1960 tentang Peraturan Dasar Pokok-Pokok Agraria di dalam Pasal 19 menyatakan untuk menjamin kepastian hokum oleh Pemerintah diadakan pendaftaran tanah di seluruh wilayah Republik Indonesia menurut ketentuanketentuan yang diatur dengan peraturan pemerintah (Sumarja, 2012;17).

Tujuan pemerintah mengadakan pendaftaran tanah dan penerbitan sertifikat merupakan salah satu perwujudan dari tujuan pendaftaran tanah yang dimaksud. UndangUndang Nomor 5 Tahun 1960 tentang Peraturan Dasar Pokok-Pokok Agraria (UUPA), melalui Pasal 19 mengamanatkan bahwa pemerintah mengadakan pendaftaran tanah untuk seluruh wilayah Republik Indonesia dan bahwa sertifikat hak atas tanah merupakan bukti yang kuat mengenai suatu penguasaan atau pemilikan tanah (Sumarja, 2012;9-10).

Hasil evaluasi yang dilakukan oleh kantor Badan Pertanahan Nasional dan Bank Dunia antara lain menyatakan bahwa selama lebih dari 35 tahun pelaksanaan Undang-Undang Pokok Agraria, Badan Pertanahan Nasional telah melaksanakan pendaftaran tanah dengan landasan kerja dan landasan hukum Peraturan Pemerintah Nomor 10 Tahun 1961. Dengan keterbatasan yang ada sampai tahun 1997 telah berhasil mendaftar +18 juta bidang tanah. Namun demikian hasil tersebut dipandang kurang memadai, karena jumlah bidang tanah yang ada di seluruh Indonesia diperkirakan 75 juta bidang sehingga masih banyak tanah-tanah yang belum didaftar.

Berkenaan dengan hal tersebut dalam penjelasan UUPA angka II butir 2 disebutkan 
negara bukan pemilik tanah tetapi lebih tepat sebagai organisasi kekuasaan dari seluruh rakyat (bangsa) yang bertindak sebagai badan penguasa. Dari sudut pandang inilah harus dilihat ketentuan Pasal 2 ayat (1) UUPA yang menyatakan bahwa, "Bumi, air, dan ruang angkasa, termasuk dikuasai oleh negara". Dalam rangka mewujudkan kehadiran Negara di bidang pertanahan dengan memberikan jaminan kepastian hukum Hak Atas Tanah sebagai bukti hak kepemilikan sebagaimana diamanatkan dalam pasal 19 Undang-Undang Nomor 5 Tahun 1960 tentang Peraturan Dasar Pokok-Pokok Agraria, pemerintah berkewajiban menyelenggarakan pendaftaran tanah di seluruh wilayah Republik Indonesia. Oleh karena itu perlu dilakukan percepatan pendaftaran tanah untuk mengejar prosentase tanah terdaftar yang masih di bawah $50 \%$ pada tahun 2017. Salah satu cara yang ditempuh Kementerian Agraria dan Tata Ruang adalah melalui program Percepatan Pelaksanaan Pendaftaran Tanah Sistematis Lengkap sebagaimana diatur dalam Peraturan Menteri Agraria dan Tata Ruang/Kepala Badan Pertanahan Nasional Nomor 35 Tahun 2016 tentang Percepatan Pelaksanaan Pendaftaran Tanah Sistematis Lengkap.

Bertujuan untuk mempercepat pelaksanaan pendaftaran tanah, Kantor Menteri Negara/Badan Pertanahan Nasional membuat perencanaan selama 25 tahun untuk menyelesaikan pensertipikatan tanah di seluruh wilayah Republik Indonesia. Upaya percepatan pendaftaran tanah dilakukan dengan pendekatan sistematik melalui Proyek Administrasi Pertanahan di mana sebagian dananya dibiayai oleh Bank Dunia. Satu hal yang merupakan terobosan pemerintah adalah memperkenalkan Tim Ajudikasi sebagai institusi pendaftaran tanah sistematik yang mempunyai kewenangan sederajat dengan Kepala Kantor Pertanahan Kotamadya/Kabupaten (Harsono, 2007). Salah satu langkah yang dilakukan oleh Kementrian ATR BPN dengan melaksanakan program nasional agraria dan pendaftaran tanah sistematis lengkap.

Melalui program pelaksanaan program nasional agraria (PRONA) pemerintah juga melaksanakan pendaftaran tanah sistematis lengkap (PTSL) yaitu kegiatan pendaftaran tanah untuk pertama kali (baik pendaftaran tanah pertama kali Konversi/ Pengakuan/ Penegasan Hak ataupun pendaftaran tanah pertama kali pemberian hak) yang dilakukan secara serentak yang meliputi semua obyek pendaftaran tanah yang belum didaftar dalam suatu wilayah desa/kelurahan atau nama lainnya yang setingkat dengan itu (Kementerian ATR BPN, 2017). Pendaftaran tanah dan penerbitan sertifikat bertujuan untuk memberikan kepastian hukum atas hak milik atas tanah dan untuk menciptakan tertib administrasi pertanahan (Sahprada, 2018). Dengan pendaftaran tanah sistematik menghasilkan peta pendaftaran tanah yang memuat peta bidangbidang tanah yang didaftar secara terkonsolidasi dan terhubung dengan titik ikat tertentu, sehingga di kemudian hari dapat dilakukan rekonstruksi batas dengan mudah. Dengan demikian dapat dihindarkan adanya sengketa mengenai batas bidang tanah yang sampai sekarang masih sering terjadi.

Penyelenggaraan pendaftaran tanah menghasilkan suatu produk akhir yaitu berupa sertifikat sebagai tanda bukti kepemilikan hak atas tanah. Namun dalam pelaksanaannya, pasti ada hambatan, baik dalam pelaksanaan administrasi maupun dari masyarakat itu sendiri. Masyarakat masih ada yang belum begitu mengerti akan pentingnya suatu pendataan tanah (Soerodjo I, 2002;40). Pemegang hak atau tanah berhak mendapatkan bukti otentik yang berkekuatan hukum tentang kepemilikan tanahnya dari lembaga yang berwenang, yaitu Badan Pertanahan Nasional.

Desa Kinabuhutan merupakan salah satu desa pulau yang berada di ujung utara wilayah Kabupaten Minahasa Utara dengan luas daratan 65 ha. Secara administratif desa ini berbatasan dengan Pulau Biaro di sebelah utara; Pulau Gangga di sebelah selatan, pulau Bangka di sebelah timur, dan Pulau Talise di sebelah barat. Desa Kinabuhutan merupakan desa definitif tahun 2005 sebagai hasil pemekaran dari Desa Talise Tambun yang pada tahun 1880 merupakan lahan perkebunan kelapa milik Belanda (Mantjoro, 1997).

Jumlah penduduk desa Kinabuhutan tahun 2007 tercatat 1.089 jiwa (51,52\% laki- 
laki dan 48,48\% perempuan), dengan usia tenaga kerja produktif (16 - 50 tahun) tercatat $58,31 \%$ dan tidak produktif $(<15$ tahun $)$ atau kurang produktif (> 51 tahun) 41,69\%. Penduduknya sebagian besar (90\%) beragama Islam, sisanya beragama Kristen Protestan. Tingkat pendidikan masyarakat secara umum masih rendah, karena sebagian besar penduduknya hanya tamatan SD kemudian diikuti SLTP. Hal ini kemungkinan disebabkan kurangnya sarana dan prasarana pendidikan yang tersedia (hanya 1 SD Inpres dan 1 SMP terbuka yang menerima siswa baru mulai 1995). Ketika melanjutkan studi ke SMU, lulusan SLTP harus ke ibukota kecamatan (Likupang) dan ini akan sangat membebani para orangtua alam hal biaya transportasi. Berdasarkan data yang terdapat pada profil Desa Kinabuhutan tahun 2007, diperoleh bahwa dari 303 orang penduduk yang memiliki mata pencaharian, $78,55 \%$ di antaranya adalah nelayan, kemudian disusul pedagang atau tibo-tibo (11,55\%), petani $(3,30 \%)$, pengusaha $(3,30 \%)$, dan tukang atau buruh $(2,31 \%)$, sisanya $(0,99 \%)$ adalah guru (PNS). Secara umum Desa Kinabuhutan merupakan daerah yang masih jauh dikatakan sebagai daerah yang maju hal tersebut dikarenakan masih banyaknya pemukiman padat penduduk meskipun terdapat beberapa wilayah yang sudah teratur rapih dengan kategori kondisi pemukiman dengan kategori sederhana sampai menengah.

Pelaksanaan PRONA dan PTSL di Desa Kinabuhutan Kecamatan Likupang Barat, sudah pernah dilaksanakan. Desa Kinabuhutan Kecamatan Likupang Barat dijadikan sebagai lokasi penelitian dikarenakan sebelumnya Desa Kinabuhutan telah dilaksanakan kegiatan Program Nasional Agraria (PRONA) pada Tahun 2016 dan Tahun 2017 menjadi salah satu desa dalam program baru pemerintah yaitu kegiatan Percepatan Pelaksanaan Pendaftaran Tanah Sistematis Lengkap (PTSL).

Kegiatan PRONA dilakukan sejak tahun 2016 dan kegiatan PTSL dilakukan pada tahun 2017. Dalam rangka pengembangan, pendaftaran tanah dilakukan untuk mendapatkan kepastian hukum atas tanah (sertipikat) benar- benar sesuai dengan tujuan pelaksanaan Program Nasional Agraria
(PRONA) dan percepatan pelaksanaan pendaftaran hak atas tanah (PTSL) sehingga perlu di evaluasi untuk mempercepat pembangunan wilayah di Kabupaten Minahasa Utara khususnya di Desa Kinabuhutan agar kepastian hukum dan perlindungan hukum hak atas tanah rakyat secara pasti, sederhana, cepat, lancar, aman, adil, merata dan terbuka serta akuntabel, sehingga dapat meningkatkan kesejahteraan dan kemakmuran rakyat dalam percepatan pembangunan wilayah di Kabupaten Minahasa Utara.

Berdasarkan uraian di atas dan untuk mengetahui sejauhmana pelaksanaan program nasional agraria (PRONA) dan pendaftaran tanah sistematik lengkap (PTSL) terhadap tertib pertanahan di Desa Kinabuhutan Kecamatan Likupang Barat Kabupaten Minahasa Utara, peneliti merasa tertarik untuk melakukan penelitian dalam bentuk tesis dengan judul: "Evaluasi Pelaksanaan Program Nasional Agraria Dan Pendaftaran Tanah sistematis Lengkap Dalam Pembangunan Wilayah Desa Kinabuhutan Kecamatan Likupang Barat Kabupaten Minahasa Utara“.

\section{Rumusan Masalah}

Berdasarkan latar belakang di atas, rumusan masalah dalam penelitian ini ialah bagaimana pelaksanaan program nasional agrarian dan pendaftaran tanah sistematis lengkap dalam pembangunan wilayah Desa Kinabuhutan Kecamatan Likupang Barat Kabupaten Minahasa Utara?

\section{Tujuan Penelitian}

Penelitian ini bertujuan untuk mengetahui evaluasi pelaksanaan program nasional agrarian dan pendaftaran tanah sistematis lengkap dalam pembangunan wilayah Desa Kinabuhutan Kecamatan Likupang Barat Kabupaten Minahasa Utara.

\section{Manfaat Penelitian}

1. Manfaat Teoritis

a) Menambah khasanah ilmu pengetahuan khususnya dalam bidang pengembangan pembangunan.

b) Dapat menambah literatur bahan kajian penelitian dalam pengembangan objek wisata Danau bagi peneliti-peneliti selanjutnya. 
2. Manfaat Praktis

a) Bagi peneliti: menambah wawasan tentang pelaksanaan program nasional agrarian dan pendaftaran tanah sistematis lengkap dalam pembangunan wilayah Desa Kinabuhutan Kecamatan Likupang Barat Kabupaten Minahasa Utara.

b) Bagi masyarakat: menjamin kepastian hukum, terhindar dari terjadinya tumpang tindih, kepemilikan tanah yang jelas sehingga dengan memperoleh sertipikat hak atas tanah masyarakat lebih mudah memperoleh modal dalam mengembangkan usahanya demi meningkatkan kesejahteraan perekonomian

c) Bagi pendidikan: menjadi salah satu sumbangan pemikiran dalam bidang pembangunan wilayah melalui pelaksanaan program nasional agrarian dan pendaftaran tanah sistematis lengkap.

d) Kantor Pertanahan: sebagai bahan masukan kepada Pemerintah Kabupaten Minahasa Utara khususnya Kantor Pertanahan dalam pelaksanaan program nasional agrarian dan pendaftaran sistematis lengkap dan diharapkan dapat membantu Pemerintah Kabupaten Minahasa Utara dalam merumuskan hasil evaluasi pelaksanaan program nasional agrarian dan pendaftaran tanah sistematis lengkap dalam pembangunan wilayah Desa Kinabuhutan Kecamatan Likupang Barat Kabupaten Minahasa Utara.

\section{METODOLOGI PENELITIAN}

\section{Jenis Penelitian}

Jenis penelitian yang digunakan dalam penelitian ini adalah metode deskriptif dengan pendekatan penelitian kualitatif yaitu menggambarkan atau melukiskan keadaan subjek dan objek, baik seseorang, lembaga, masyarakat, dan lain sebagainya, serta didasarkan atas hasil observasi yang dilaksanakan serta memberikan argumentasi terhadap apa yang ditemukan di lapangan dan dihubungkan dengan konsep teori yang relevan.

\section{Tempat dan Waktu Penelitian}

Penelitian ini dilaksanakan di Desa Kinabuhutan Kecamatan Likupang Barat Kabupaten Minahasa Utara Propinsi Sulawesi Utara yang dilaksanakan pada bulan Juni Tahun 2017 sampai dengan bulan Januari 2018.

\section{Populasi, Sampel dan Teknik Pengambilan Sampel}

\section{Populasi}

Populasi penelitian terdiri dari pelaksana dan peserta yang telah mengikuti PRONA yang berjumlah 275 orang dan PTSL

75 orang di Desa Kinabuhutan Kecamatan Likupang Barat Kabupaten Minahasa Utara yang dijadikan sebagai responden. Responden dalam penelitian ini adalah semua pihak yang terkait di dalam kebijakan PRONA dan PTSL serta dapat memberikan data serta informasi, serta mengetahui dan mengerti masalah yang sedang diteliti.

\section{Sampel}

Sampel penelitian terdiri dari 23 responden untuk PRONA dan 21 responden untuk PTSL.

\section{Teknik Pengambilan Sampel}

Penentuan sampel dilakukan dengan menggunakan teknik Purposive sampling dimana jumlah sampel ditentukan oleh peneliti berdasarkan pertimbangan yang terdiri dari: Alasan dipilihnya objek tersebut didasarkan pada ciri-ciri dasar kepemilikan tanah pemiliknya berada ditempat dan menguasai secara fisik, jelas sifat-sifat dilihat dari dasar- dasar pembuatan sertipikat (manfaat dan tujuan pembuatan sertipikat misalnya untuk modal usaha dan hanya untuk sebagai pemegang hak kepastian hukum) dan karakteristik status social misalnya pemuka masyarakat kepala desa, pemuka agama, toko- toko agama pemerintah sebagian dan sebagian masyarakat umum dari masingmasing sampel yang sudah mewakili populasi yang ada. 


\section{Variabel Penelitian}

Variabel dalam penelitian ini terdiri dari:

1. Program Nasional Agraria

Semua kegiatan yang diselenggarakan oleh pemerintah di bidang pertanahan dengan suatu subsidi di bidang pendaftaran tanah pada khususnya, yang berupa pensertipikatan tanah secara massal dalam rangka membantu masyarakat golongan ekonomi lemah.

2. Pendaftaran Tanah Sistematis Lengkap

Kegiatan pendaftaran tanah untuk pertama kali yang dilakukan secara serentak yang meliputi semua obyek pendaftaran tanah yang belum didaftar dalam satu wilayah desa atau kelurahan atau nama lainnya yang setingkat dengan itu.

3. Pengembangan wilayah

Pembangunan yang didalamnya terdaftar unsur tata ruang dan lokasi kegiatan ekonomi dan social secara terintegrasi.

\section{Teknik Pengumpulan Data}

Metode pengumpulan data yang digunakan adalah sebagai berikut:

1. Observasi

Observasi merupakan pengamatan intensif terhadap objek penelitian yaitu dengan mendatangi Desa Kinabuhutan Kecamatan Likupang Barat Kabupaten Minahasa Utara sebagai lokasi penelitian dengan mengamati secara langsung situasi dan kondisi dari objek penelitian.

2. Wawancara

Wawancara merupakan kegiatan informasi komunikasi verbal yang bertujuan untuk mendapatkan berupa data primer dari informan. Wawancara dilakukan dengan masyarakat yang menjadi sampel dalam penelitian bersama pelaksana PRONA dan PTSL di Desa Kinabuhutan Kecamatan Likupang Barat Kabupaten Minahasa Utara serta masyarakat yang sedang mengurus sertifikat tanah.

3. Dokumentasi

Dokumentasi adalah teknik mengumpulkan dokumen-dokumen yang berkaitan dengan penelitian, dan mempelajari catatan- catatan mengenai data pribadi responden.

\section{Jenis dan Sumber Data}

Jenis dan sumber data yang digunakan dalam penulisan ini adalah sebagai berikut :

1. Data Primer.

Data primer merupakan data yang diperoleh secara langsung dari lapangan atau tempat penelitian. Penelitian yang dilakukan dari sumbernya melalui wawancara dan observasi dengan pihak yang menjadi objek penelitian.

a. Data yang diperoleh langsung dari objek penelitian di Desa Kinabuhutan Kecamatan Likupang Barat Kabupaten Minahasa Utara.

b. Informasi tentang pelaksanaan kebijakan PRONA dan PTSL di Kabupaten Minahasa Utara khususnya di Desa Kinabuhutan Kecamatan Likupang Barat.

2. Data Sekunder

Data sekunder adalah data yang diperoleh dari sumber kedua atau sumber sekunder dari data yang kita butuhkan, seperti:

a. Data berupa dokumen tentang pelaksanaan kebijakan PRONA dan PTSL yang telah dilakukan oleh Badan Pertanahan Nasional di Kabupaten Minahasa Utara khususnya di Desa Kinabuhutan Kecamatan Likupang Barat.

b. Data tentang program dan perencanaan yang telah dilakukan oleh pihak di Kabupaten Minahasa Utara khususnya di Desa Kinabuhutan Kecamatan Likupang Barat.

c. Gambaran umum tentang kebijakan PRONA dan PTSL

d. Buku-buku yang dapat mendukung dan menjelaskan masalah yang sedang diteliti.

\section{Teknik Analisis Data}

Teknik analisis data yang digunakan dalam penelitian ini adalah deskriptif kualitatif. Teknik analisis data deskriptif kualitatif adalah teknik analisis data yang mengungkapkan kejadian atau fakta, keadaan, fenomena, variabel dan keadaan yang terjadi saat penelitian berlangsung dengan menyuguhkan apa yang sebenarnya terjadi. Penelitian ini menafsirkan, menguraikan dan mengevaluasi 
data yang bersangkutan dengan situasi yang sedang terjadi, sikap serta pandangan yang terjadi di dalam suatu masyarakat, pertentangan antara dua keadaan atau lebih, hubungan antar variabel yang timbul, perbedaan antar fakta yang ada serta pengaruhnya terhadap suatu kondisi, dan sebagainya dalam hal pelaksanaan PRONA dan PTSL di Desa Kinabuhutan Kecamatan Likupang Barat Kabupaten Minahasa Utara.

\section{HASIL DAN PEMBAHASAN}

\section{Gambaran Umum Kabupaten Minahasa Utara}

Letak geografis Kabupaten Minahasa Utara antara $124^{\circ} 40^{\prime} 38,39^{\prime \prime}$ - $125^{\circ} 15^{\prime}$ 15,53'”BT dan 1'17'51,93'” - 1'56'41,03''LU. Batas Wilayah Minahasa Utara sebagai berikut:

1. Utara : Kabupaten Kepulauan Sangihe dan Laut Sulawesi,

2. Timur : Kota Bitung dan Laut Maluku,

3. Barat : Kota Manado dan Laut Sulawesi, dan

4. Selatan : Kabupaten Minahasa.

Secara administrasi luas wilayah Kabupaten Minahasa Utara sebesar $1.261 \mathrm{~km}^{2}$ yang terbagi pada 10 Kecamatan dan 124 Desa/Kelurahan dengan jumlah penduduk pada Tahun 2010 sebanyak 188.407 jiwa. Pembagian wilayah dapat dilihat pada Tabel 1 .

\begin{tabular}{|c|c|c|c|c|c|c|}
\hline & \multirow{3}{*}{$\begin{array}{l}\text { Kecamatan } \\
\text { Subdistric }\end{array}$} & \multirow{3}{*}{$\begin{array}{l}\begin{array}{l}\text { Luss } \\
\text { (Area) }\end{array} \\
\left(\text { Kim }^{2}\right)\end{array}$} & \multirow{2}{*}{\multicolumn{3}{|c|}{$\begin{array}{l}\text { Pendudusk } \\
\text { Pepulation }\end{array}$}} & \multirow{3}{*}{ 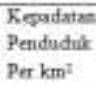 } \\
\hline & & & & & & \\
\hline & & & (क) & Pomish & (5) & \\
\hline & (1) & (2) & (3) & (4) & (5) & (6) \\
\hline I. & Kemix & 78,76 & 7,44 & 16746 & 8,39 & 212,62 \\
\hline 2. & Ksuditan & 108,20 & 10,21 & 2467 & 12,26 & 226,13 \\
\hline 3. & Airmadidi & 86,66 & 8,18 & 28833 & 14,45 & 332,71 \\
\hline 4. & Kalawat & 39,03 & 3,68 & 31225 & 15,65 & 800,03 \\
\hline 5. & Dimenbe & 166,43 & 15,71 & 23855 & 11,96 & 143,33 \\
\hline 6. & Talawan & 82,51 & 7,79 & 21038 & 10.55 & 254,98 \\
\hline 7. & Wen & 90,70 & 8,56 & 16879 & 8,46 & 186,10 \\
\hline 8 & Liknoung Basat & $10+29$ & 9,85 & 16049 & 8,04 & 153,89 \\
\hline 9. & Liloopang Tlawe & 290,84 & 27,46 & 15540 & 7,79 & 53,43 \\
\hline 10 & Likrapang Selatun & 11.82 & 1,12 & 4866 & 2,44 & 411,68 \\
\hline & Minabasa Utara & 1059,24 & 100,00 & 199498 & 100,0 & 188,34 \\
\hline
\end{tabular}

Kabupaten Minahasa Utara dengan pusat pemerintahan dan ibukota di Airmadidi di Provinsi Sulawesi Utara. Kabupaten Minahasa Utara memiliki lokasi yang strategis karena berada diantara dua kota yaitu Kota Manado dan kota Bitung Kabupaten Minahasa Utara terdiri dari 10 kecamatan.

Tipe iklim diwilayah ini yaitu iklim tropis yang cenderung basah dimana pada bulan Mei Oktober yaitu musim kemarau dan bulan November - April merupakan musim penghujan. Rata-rata temperatur atau suhu udara di daerah pantai adalah berkisar pada 28$31^{\circ} \mathrm{C}$, dan di daerah dataran pemukiman sekitar $27-30^{\circ}$ C. Kondisi iklim dan topografi ini sekaligus dapat menggambarkan keadaan wilayah Kabupaten Minahasa Utara sebagai daerah yang subur dan berpotensi besar di masa mendatang untuk pengembangan sentra-sentra produksi pertanian tanaman pangan, holtikultura, perkebunan dan kehutanan serta ditunjang oleh ketersediaan sumberdaya kelautan dan perikanan yang sangat berlimpah disamping juga memiliki basis-basis kawasan industri, jasa dan perdagangan serta potensi pertambangan yang tentunya semua itu sangat mendukung bagi nilai-nilai investasi guna perkembangan kemajuan daerah kedepan.

\section{Gambaran Umum Lokasi penelitian Desa Kinabuhutan}

Desa Kinabuhutan berdiri pada tahun 2006 yang dahulunya Desa Talise dan dipisahkan sesuai SK Bupati Minahasa Utara tentang Pemekaran/ Pembentukan Desa resmi pada tahun 2007, dengan luas tanah 742.764, jumlah Penduduk Kinabuhutan 520 Penduduk, jarak dari Airmadidi ke Desa Kinabuhutan \pm 43 KM.

Jumlah penduduk 1.187 orang dan terdiri dari 331 KK.Penduduk yang bermukim di Desa tersebut pada umumnya pendatang yang berasal dari Desa Kimabajo dan dari Kepulauan Sangihe. Mata Pencaharian penduduk sebagian besar yaitu nelayan. Rumah tangga nelayan memiliki ciri khusus seperti penggunaan wilayah pesisir dan laut (common property) sebagai faktor produksi, jam kerja harus mengikuti kondisi oseanografis (melaut hanya rata-rata sekitar 20 hari dalam satu bulan, sisanyarelatif menganggur). Demikian juga pekerjaan menangkap ikan adalah pekerjaan yang penuh resiko, sehingga pekerjaan ini umumnya dikerjakan oleh lelaki. Hal ini mengandung arti bahwa keluarga yang lain tidak dapat membantu secara penuh, sehingga masyarakat yang tinggal di wilayah pesisir pada umumnya sering di identikkan dengan masyarakat miskin. 
Tata Cara Pelaksanaan PRONA dan PTSL di Kabupaten Minahasa Utara

a. Pelaksanaan PRONA

Kegiatan PRONA pada prinsipnya merupakan kegiatan pendaftaran tanah pertama kali dalam rangka penerbitan sertipikat hak atas tanag yang diperuntukkan untuk warga Negara Indonesia atau badan hukum/ lembaga sosial dan keagamaan. Tahapan pelaksanaan kegiatan PRONA di Kabupaten Minahasa Utara telah dilakukan tahapan tahapan sebagai berikut:

1) Penetapan lokasi

Lokasi PRONA Tahun 2016 di Kantor Pertanahan Kabupaten Minahasa Utara sesuai dengan keputusan terdiri dari 28 desa yang mengikuti PRONA salah satunya Desa Kinabuhutan yang saat ini menjadi objek penelitian

2) Penunjuk Peserta

Penunjuk calon peserta PRONA berdasarkan nama - nama yang masuk dari Kelurahan dan nama - nama yang masuk ikut peserta PRONA dengan jumlah 271 bidang.

3) Tahapan Persiapan

Persiapan meliputi pembentukan tim PRONA, menyediakan alat dan bahan yang akan digunakan berupa: rencana sertipikat yang akan diterbitkan; alat ukur yang digunakan, ATK, formulir - formulir, kertas peta

4) Tahapan Pelaksanaan

a) Penyuluhan dari Kantor Pertanahan

Penyuluhan dilakukan oleh satuan

tugas yang khusus memberikan penyuluhan kepada masyarakat mengenai pentingnya sertipikat tanah di Desa Kinabuhutan.

b) Pengumpulan data dilapangan

Pengumpulan data dilapangan berupa pengukuran tanah dan pemetaan, serta pemberian tanda batas ada masingmasing bidang tanah yang telah diukur. Pengukuran ini dilakukan oleh para satuan tugas ukur dari satuan tugas PRONA yang ditetapkan.

c) Pengisian formulir permohonan pemilikan tanah
Pengisian formulir permohonan pemilikan tanah secara fisik serta pengisian mengenai risalah penelitian yuridis dan penetapan batas, dilakukan oleh petugas. Formulir diisi sesuai sesuai dengan data yang yang terdapat dari hasil penelitian dilapangan.

d) Pengumuman

Pengumuman diproses melalui Kantor Desa/ Kelurahan atau Kantor Kecamatan.

e) Pengolahan Data

Pengolahan data dilakukan oleh tim yang masuk dalam kegiatan PRONA.

f) Penerbitan/ penyelesaian akhir sertipikat

Setelah data- data diperiksa oleh petugas dan telah diakui kebenarannya dan dapat dipertanggungjawabkan, selanjutnya dilakukan buku tanah dan proses pembuatan sertipikat yaitu penjilidan dan penyalinan data dari buku tanah dan menjadi sertipikat.

g) Penyerahan Sertipikat

Penyerahan dilakukan padaa saat dikumpulkan semua pemohon yang terdaftar dalam kegiatan PRONA.

Mekanisme pelaksanaan kegiatan PRONA dapat digambarkan sesuai dengan bagan dibawah ini:

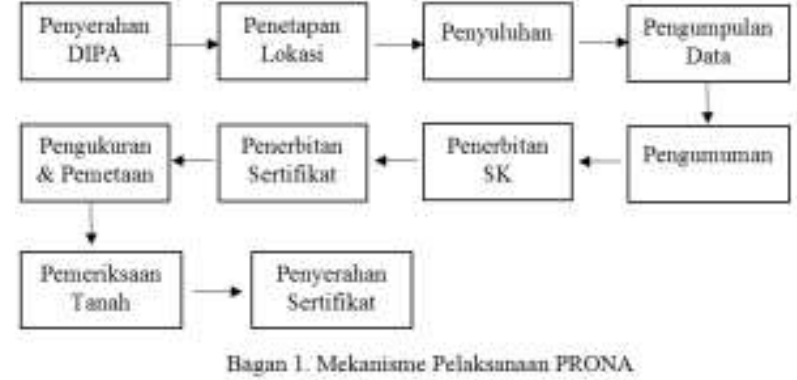

b. Pelaksanaan PTSL

Program Pendaftaran Tanah Sistematis Lengkap (PTSL) adalah kegiatan pendaftaran tanah untuk pertama kali (baik pendaftaran pertama kali konversi/ pengakuan/ penegasan hak ataupun pendaftaran tanah pertama kali pemberian hak) yang dilakukan secara serentak yang meliputi semua obyek pendaftaran tanah yang belum didaftar dalah suatu wilayah desa/ kelurahan atau nama lainnya yang 
setingkat dengan itu, meliputi tahapan sebagai berikut:

1) Penetapan Lokasi

$$
\text { Lokasi yang ditetapkan }
$$

berdasarkan peta kerja yang tersedia dilokasi mana yang akan mencapai target dan salah satunya Desa Kinabuhutan Kabupaten Minahasa Utara dan semua pesertaharus terdaftar dalam kegiatan PTSL baik dalam pengukuran maupun pembuatan sertipikat.

2) Pengumpulan Data Yuridis

Tim pengumpulan data yuridis melaksanakan pengumpulan data sesuai dengan target yang telah ditentukan sejumlah 75 bidang.

3) Pengukuran

Tim Pengukuran melaksanakan pengukuran setelah ada peta kerja dan data yuridis

4) Pengolahan Data Yuridis

Setelah terkumpul dari tim panitia melaksanakan analisis data dan dikelompokkan.

5) Pemeriksaan Tanah

Tim Panitia mengadakan pemeriksaan tanah untuk memastikan keterangan yang tertuang di dalam data yuridis sesuai dengan keadaan dilapangan.

6) Pengumuman

Pengumuan dilaksanakan di Kantor Pertanahan, Kantor Desa, Sekretariat RT/RW di lokasi bidang tanah selama 14 hari.

7) Pengesahan

Hasil dari pengumuan disahkan dalam berita acara hasil pengumuman oleh Panitia Ajudikasi.

8) Pembukuan Hak

$$
\text { Panitia }
$$

Ajudikasi

mendokumentasikan seluruh warkah/ dokumen data fisik maupun yuridis

9) Penerbitan dan Penyerahan Sertipikat

Penyerahan dilaksana kan sesuai dengan waktu yang ditentukan dan para peserta dikumpulkan untuk diserahkan secara bersama.

\section{Hasil Wawancara dan Observasi \\ Pelaksanaan PRONA di Desa Kinabuhutan Kecamatan Likupang Barat}

\section{Hasil Wawancara}

1) Pelaksana PRONA

Berkaitan dengan pendaftaran tanah secara sistematik tidak terpenuhi dan letak tanah obyek PRONA tersebar dalam lokasi desa/kelurahan yang ditetapkan, maka dapat menggunakan pendekatan pendaftaran tanah secara sporadik. Proses pendaftaran tanah Kegiatan PRONA dilakukan sebagai berikut:

a) Pembuktian hak lama yang alat bukti tertulisnya lengkap, tidak lengkap atau tidak ada sama sekali berdasarkan ketentuan Peraturan Pemerintah Nomor 24 Tahun 1997 jo. Peraturan Menteri Negara Agraria/Kepala BPN Nomor 3 Tahun 1997, pendaftaran lainnya dilakukan melalui proses penegasan konversi atau pengakuan hak;

b) Pembuktian hak baru atas Tanah Negara, berdasarkan Peraturan Pemerintah Nomor 24 Tahun 1997 jo. Peraturan Menteri Negara Agraria/Kepala Badan Pertanahan Nasioanal Nomor 3 Tahun 1997 dan Peraturan Menteri Negara Agraria/Kepala Badan Pertanahan Nasional Nomor 9 Tahun 1999, pendaftaran tanahnya dilakukan melalui proses surat keputusan pemberian hak atas tanah.

Di Desa Kinabuhutan Kecamatan Likupang Barat Kabupaten Minahasa Utara dalam menyikapi PRONA sangat beragam, ada yang mengapresiasi dengan kurang baik, baik, hingga sangat baik. Hasil wawancara dengan pelaksana PRONA yang menjadi kendala terutama adalah kurang siapnya dan ketidakpahaman masyarakat peserta PRONA dalam melengkapi berkas persyaratan terutama berkas yang menyangkut masalah alas hak/ kepemilikan. Tanggapan masyarakat terhadap pelaksanaaan PRONA 70 persen menyatakan sangat baik dan 30 persen mengatakan cukup baik.

Menurut pelaksana, masalah yang sering terjadi yaitu masalah tanda batas sehingga menimbulkan sengketa tanah. Masalah yang dari pelaksana adalah sering terhambat karena kurangnya SDM. Kelebihan PRONA Menurut Pelaksana kelebihannya yaitu program PRONA dilakukan secara masal dan gratis bagi masyarakat untuk mendapat kepastian hukum berdasarkan sertipikasi tanah. Sedangkan yang menjadi Kelemahan atau kekurangan dalam program 
PRONA adalah adalah dari sisi pemetaan keseluruahan karna Prona hanya dilakukan dengan sporadik yang tidak menyeluruh untuk pengukuran bidang tanah, kemudian adanya masalah tanda batas kepemilihan tanah sehingga tidak bisa diukur. Hasil wawancara terhadap pelaksana PRONA disajikan pada Tabel 2 dibawah ini:

Tabel 2. Hasil Wawancara Terhadap Pelaksana PRONA

\begin{tabular}{|c|c|c|}
\hline No. & Pertanyaan & Kesimpulan \\
\hline 1. & $\begin{array}{l}\text { Apa yang menjadi kendala } \\
\text { dalam pelaksanaan } \\
\text { kegiatan PRONA? }\end{array}$ & $\begin{array}{lcr}\text { Menurut P elaksana P } & \text { RONA, } \\
\text { masyarakat kurang siap merespon } \\
\text { kegiatan } & \text { PRONA } & \text { dan } \\
\text { ketidakpahaman masyarakat akan } & \\
\text { kelengkapan berkas }\end{array}$ \\
\hline 2. & $\begin{array}{l}\text { Masalah apa yang sering } \\
\text { ditemukan pada saat } \\
\text { pelaksanaan kegiatan } \\
\text { P RONA? }\end{array}$ & $\begin{array}{l}\text { Menurut P elaksana P RONA, masalah } \\
\text { Alas Hak/ kepemilikan, dan batas } \\
\text { bidang tanah. }\end{array}$ \\
\hline 3. & $\begin{array}{l}\text { Sebagai petugas apakah } \\
\text { anda merasa mana yang } \\
\text { lebih muda untuk } \\
\text { dikerjakan antara P RONA } \\
\text { dan P TSL? }\end{array}$ & $\begin{array}{l}\text { Menurut P elaksana, kedua- duanya } \\
\text { muda dikerjakan hanya saja P RONA } \\
\text { untuk bidang tertentu dan P TSL } \\
\text { diukur untuk semua bidang tanah } \\
\text { secara lengkap. }\end{array}$ \\
\hline 4. & $\begin{array}{lr}\text { Bagaimana } & \text { sambutan } \\
\text { masyarakat } & \text { terhadap } \\
\text { kegiatan PRONA? }\end{array}$ & $\begin{array}{l}\text { Menurut P elaksana } P \text { RONA, } \\
\text { sambutan masyarakat } 70 \text { persen } \\
\text { mengatakan sangat baik dalam } \\
\text { menyambut kami petugas BP N } 30 \\
\text { persen mengatakan cukup baik }\end{array}$ \\
\hline 5. & $\begin{array}{l}\text { Jika ditemukan masalah } \\
\text { dalam lapangan, } \\
\text { contohnya tanah tersebut } \\
\text { tidak boleh diukur karena } \\
\text { bermasalah, bagaimana } \\
\text { anda menjelaskannya? }\end{array}$ & $\begin{array}{l}\mathrm{P} \text { ada umumnya diselesaikan dengan } \\
\text { cara mediasi kedua belah pihak yang } \\
\text { bermasalah apakah masalah batas } \\
\text { atau kepemilikan tanah. }\end{array}$ \\
\hline 6. & $\begin{array}{l}\text { Menurut anda apakah } \\
\text { kegiatan P RONA dapat } \\
\text { membantu masyarakat? }\end{array}$ & $\begin{array}{l}\text { Menurut pelaksana PRONA, kegiatan } \\
\text { PRONA sangat membantu karena ada } \\
\text { kepastian hukum atas hak atas tanah. }\end{array}$ \\
\hline 7. & $\begin{array}{l}\text { Apakah pada saat } \\
\text { penyelesaian penerbitan } \\
\text { Sertipikat Hak Atas Tanah } \\
\text { kegiatan P RONA sering } \\
\text { terhambat? }\end{array}$ & $\begin{array}{l}\text { Menurut P elaksana, sering terhambat } \\
\text { karena kurangnya SDM }\end{array}$ \\
\hline 8. & $\begin{array}{l}\text { Apakah yang menjadi } \\
\text { kelebihan/ keuntungan } \\
\text { dalam kegiatan P RONA? }\end{array}$ & $\begin{array}{l}\text { Menurut P elaksana Kelebihannya } \\
\text { yaitu kegiatan P RONA dilakukan } \\
\text { secara masal dan gratis masyarakat } \\
\text { mendapat kepastian hukum } \\
\text { berdasarkan Sertipikasi tanah }\end{array}$ \\
\hline 9 & $\begin{array}{l}\text { Apakah yang menjadi } \\
\text { Kelemahan / kekurangan } \\
\text { dalam kegiatan P RONA? }\end{array}$ & $\begin{array}{l}\mathrm{P} \text { rona kekurangannya adalah dari sisi } \\
\text { pemetaan keseluruahan karna } \mathrm{P} \text { rona } \\
\text { hanya dilakukan dengan sporadik yang } \\
\text { tidak menyeluruh untuk } \\
\text { pengukuran bidang tanah. }\end{array}$ \\
\hline
\end{tabular}

\section{Peserta PRONA}

Didalam pelaksanaan operasional di lapangan masih sering dijumpai Peserta Kegiatan PRONA menghadapi kendala dan masalah dalam hal pemenuhan kelengkapan dokumen pembuktian penguasaan dan kepemilikan tanah sehingga memperlambat pencapaian target tepat waktu. Terhadap dokumen pembuktian penguasaan dan kepemilikan tanah diminta kepada Kepala Kantor Wilayah, Kepala Kantor Pertanahan dan para Koordinator serta para Pelaksana Kegiatan PRONA untuk berpedoman pada Peraturan Pemerintah Nomor 24 Tahun 1997, Peraturan Menteri Negara Agraria/Kepala Badan Pertanahan
Nasional Nomor 3 Tahun 1997, Peraturan Menteri Negara Agraria/Kepala Badan Pertanahan Nasional Nomor 9 Tahun 1999 dan Peraturan Menteri Negara Agraria/Kepala Badan Pertanahan Nasional Nomor 1 Tahun 2010 serta ketentuan peraturan lainnya yang terkait.

Hasil wawancara terhadap 23 peserta PRONA, yang mengatakan sangat baik 3 responden, 16 responden menyatakan baik dan 4 responden cukup baik. Kegiatan PRONA sangat membantu masyarakat dan dari kegiatan PRONA tentunya ada kelemahannya dan ada kelebihannya karena ditemui masalah disaat penentuan tanda batas dan bukti kepemilikan seperti: alas hak (kwitansi/ jual beli) da asal usul tanah tersebut. Hasil wawancara terhadap peserta PRONA disajikan pada Tabel 4 dibawah ini:

\begin{tabular}{|c|c|c|}
\hline No & Pertanyaan & $\underline{\text { Kesimpulan }}$ \\
\hline A. & $\begin{array}{l}\text { Bagaim ana Pendapat Bapak/ Ibu } \\
\text { tentang kegiatan PRONA? }\end{array}$ & $\begin{array}{l}\text { Berdasarkan } \mathrm{j} \text { awaban dari } 23 \text { Responden } \\
\text { y ang } \mathrm{m} \text { engatakan baik } 16 \text { responden, } 3 \\
\text { responden m engatakan sangat baik, } 4 \\
\text { responden cukup baik }\end{array}$ \\
\hline B. & $\begin{array}{l}\text { Apakah pernah ada tugas dari BPN } \\
\text { yang datang mengadakan } \\
\text { peny uluhan tentang PRONA? }\end{array}$ & $\begin{array}{l}23 \text { Responden m engatakan pernah ada } \\
\text { petugas BPN y ang m engadakan peny uluhan } \\
\text { (satu kali) }\end{array}$ \\
\hline C. & $\begin{array}{l}\text { Apakah setelah diadakan } \\
\text { peny uluhan Bapak/ Ibu m engerti } \\
\text { dengan program PRONA? }\end{array}$ & $\begin{array}{l}\text { Dari } 23 \text { responden } 20 \text { orang berpendapat } \\
\text { bahwa m ereka m engerti dengan Program } \\
\text { PRONA, sedangkan } 2 \text { responden kurang } \\
\text { m engerti }\end{array}$ \\
\hline D. & $\begin{array}{l}\text { Apakah Bapak/Ibu adalah salah satu } \\
\text { peserta PRONA tahun 2017? }\end{array}$ & 23 Responden adalah peserta PRONA \\
\hline E. & $\begin{array}{l}\text { Apakah tanah y ang dim iliki Bapak/ } \\
\text { Ibu kepuny aan sendiri atau hany a } \\
\text { tanah garapan? }\end{array}$ & $\begin{array}{l}15 \text { Responden hany a tanah garapan, } 6 \\
\text { Responden adalah kepuny aan sendiri }\end{array}$ \\
\hline F. & $\begin{array}{l}\text { Apakah kegiatan PRONA sangat } \\
\text { menguntungkan bagi masy arakat }\end{array}$ & $\begin{array}{l}23 \text { Responden } \mathrm{m} \text { engatakan sangat } \\
\mathrm{m} \text { enguntungkan/m em bantu dengan adany a } \\
\text { kegiatan PRONA }\end{array}$ \\
\hline G. & $\begin{array}{l}\text { Apakah dalam proses pengurusan } \\
\text { PRONA Bapak/ Ibu m enem ukan } \\
\text { kesulitan? }\end{array}$ & $\begin{array}{l}13 \text { Responden } \mathrm{m} \text { engatakan Iy a bahwa } \\
\text { sering m enem ukan kesulitan, } 10 \text { orang } \\
\mathrm{m} \text { engatakan tidak } \mathrm{m} \text { enem ukan kesulitan } \\
\text { (y ang menj adi kesulitan y aitu peny iapan } \\
\text { dokum en untuk asal usul tanah yang } \\
\mathrm{m} \text { enj adi bukti sebagai alas hak) }\end{array}$ \\
\hline H. & $\begin{array}{l}\text { Apakah disekitar lingkungan } \\
\text { Bapak/ Ibu tinggal } \mathrm{m} \text { asih ada tanah- } \\
\text { tanah y ang belum bersertipikat? }\end{array}$ & $\begin{array}{l}23 \text { Responden } m \text { engatakan bahwa } m \text { asih } \\
\text { ada tanah- tanah y ang belum bersertipikat }\end{array}$ \\
\hline I. & $\begin{array}{l}\text { Apakah disaat pelaksanaan PRONA } \\
\text { ditem ukan } m \text { asalah seperti tanah } \\
\text { y ang tum pang tindih? }\end{array}$ & $\begin{array}{l}3 \text { Responden } m \text { engatakan } m \text { asih ada y ang } \\
\text { ditem ukan tum pang tindih, } 20 \text { Responden } \\
\text { m engatakan tidak ada lagi }\end{array}$ \\
\hline J. & $\begin{array}{l}\text { Menurut Bapak/ Ibu } \mathrm{m} \text { ana y ang } \\
\text { lebih m enguntungkan PRONA/ } \\
\text { PTSL? }\end{array}$ & $\begin{array}{l}21 \text { Responden } \mathrm{m} \text { engatakan } \mathrm{m} \text { ereka lebih } \\
\mathrm{m} \text { em ilih PRONA karena lebih } \\
\mathrm{m} \text { enguntungkan dan didaftarkan sesuai } \\
\text { dengan perm ohonan y ang } \mathrm{m} \text { asuk, } 2 \\
\text { Responden } \mathrm{m} \text { engatakan lebih } \mathrm{m} \text { em ilih } \\
\text { PTSL karena PTSL sem ua terukur sesuai } \\
\text { dengan wilay ah yang ditetapkan }\end{array}$ \\
\hline
\end{tabular}

Sumber: Hasil wawancara dari peserta Prona

\section{Hasil Observasi}

1) Penyuluhan dari KantorPertanahan

Sudah menjadi ketentuan sebelum pelaksanaan kegiatan pengumpulan data yuridis dan fisik, perlu didahului dengan melakukan penyuluhan untuk memberikan penjelasan program, tujuan serta manfaat, persyaratan permohonan hak, obyek kegiatan PRONA, hak dan kewajiban Peserta Kegiatan PRONA sesuai ketentuan peraturan 
perundangan yang berlaku. Penyuluhan bertujuan untuk memberitahukan kepada pemilik tanah atau kuasanya atau pihak lain yang berkepentingan, bahwa di desa tersebut diselenggarakan kegiatan PRONA. Diharapkan dengan penyuluhan tersebut dapat meningkatkan partisipasi, antusiasme dan kepedulian masyaratkat khususnya pemilik tanah untuk ikut serta sebagai peserta kegiatan PRONA, dan membantu kelancaran pelaksanaan kegiatan tersebut.

Berdasarkan hasil observasi dilapangan, pelaksanaan kegiatan PRONA di Kabupaten Minahasa Utara dalam tahapan melaksanakan penyuluhan sudah dilakukan. Penyuluhan dihadiri oleh masyarakat, pemerintah setempat (desa dan kecamatan) serta pihak BPN Kabupaten Minahasa Utara.

2) Pengumpulan Data Dilapangan

Pengumpulan data dilapangan meliputi pengumpulan alat bukti/ alas hak atas tanah. Pengumpulan data yuridis telah dilakukan oleh petugas yang telah ditetapkan oleh Kantor Pertanahan Kabupaten Minahasa Utara dan petugas desa setempat. Pengumpulan data yuridis meliputi pendataan calon subyek kegiatan PRONA, mengumpulkan dokumen bukti kepemilikan tanah (alat bukti hak/ alas tanah). Peserta yang terdaftar dalam kegiatan PRONA sangat antusias sehingga dibuktikan dengan masyarakat yang melengkapi berkas- berkas yang menjadi persyaratan dan petugas dari BPN juga selalu berada dilokasi untuk melayani peserta/ mayarakat.

3) Pengukuran

Pengukuran bidang tanah yang dilaksanakan dengan menggunakan alat ukur TS (Total Station) dan GPS Geodetik.

4) Pengisian Formulir Permohonan Pemilikan Tanah

Hasil inventarisasi dan identifikasi calon peserta PRONA kemudian diteliti oleh BPN Kabupaten Minahasa Utara (Tim Mobilisasi) dan bagi yang telah memenuhi syarat dan criteria yang ditentukan selanjutnya ditetapkan menjadi peserta kegiatan PRONA dengan surat keputusan Kepala Kantor Pertanahan kabupaten Minahasa Utara.

5) Pengumuman

Keperluan pendaftaran hak, hak atas tanah yang berasal dari hak-hak lama (tanah bekas milik adat dilaksanakan pengumuman data fisik dan data Yuridis di Kantor Pertanahan, di Kantor Desa/kelurahan lokasi letak tanah selama 30 (tiga puluh) hari. Petugas ukur menyiapkan Peta Bidang dan daftar data fisik. Petugas Administrasi menyiapkan Daftar Data yuridis dan Data Fisik Bidang Tanah dan Pengumuman Data Fisik dan Yuridis. Pengumuman meliputi Peta Bidang tanah dengan daftar luas masingmasing bidang, dan data kepemilikan tanah.

Pengumuman (DI 201B) berisi: Kutipan Data Yuridis dan Data Fisik yang sudah dicantumkan dalam DI 201 dimasukkan dalam DI 201C; memberi kesempatan bagi yang berkepentingan mengajukan keberatan atas data fisik dan data yuridis mengenai bidang tanah yang dimohon pendaftarannya. Apabila terdapat keberatan pada saat pengumuman data fisik dan data yuridis sebagaimana dimaksud pada angka 5 (lima), maka Kepala Kantor Pertanahan atau pejabat yang ditunjuk melakukan penelitian dan hasilnya dituangkan dalam berita acara. Hasil pengumuman data fisik dan data yuridis dibuatkan pengesahan oleh Kepala Kantor Pertanahan.

6) Pengolahan Data

Petugas pengolah data yang ditujuk sesuai dengan tugas pokok fungsinya berdasarkan SK yang dibuat oleh Kepala Kantor Pertanahan Kabupaten Minahasa Utara, menghimpun berkas permohonan yang yang telah dilengkapi dengan Surat Ukur, pengumuman untuk proses penegasan konversi atau pengakuan hak, Daftar Isian, dan Risalah Panitia Pemeriksaan Tanah. Petugas pengolah data menyiapkan telaahan dalam bentuk Risalah Pengolahan Data (RPD) sesuai dengan format yang telah ditentukan; Berkas permohonan tersebut disampaikan dengan dilengkapi daftar permohonan secara kolektif kepada Kepala Kantor Pertanahan melalui hierarki yang berlaku secara berjenjang.

7) Penerbitan/Penyelesaian Sertipikat

Hak atas tanah dan tanah wakaf didaftar dengan pembukuannya dalam buku Tanah yang memuat data fisik dan data yuridis bidang tanah yang bersangkutan. Hak atas tanah melalui penegasan konversi atau pengakuan hak dibukukan berdasarkan Berita Acara Pengesahan data fisik dan data yuridis. Hak atas tanah melalui pemberian hak, 
dibukukan berdasarkan Surat Keputusan Pemeberian Hak Atas tanah. Untuk tanah wakafmelalui penegasan konversi atau pengakuan hak dibutuhkan berdasarkan Berita Acara Pengesahan data fisik dan data Yuridis. Tanah wakaf melalui pemberian hak, dibukukan berdasarkan Surat Keputusan Pemberian Hak Atas Tanah. Untuk keperluan pendaftaran hak, setiap bidang tanah yang sudah dipetakan dalamk peta pendaftaran, dibuatkan SU. Untuk kepentingan pemegang hak atau pengelola tanah wakaf, diterbitkan sertipikat hak atas tanahwakaf.

8) Penyerahan Sertipikat

Sertipikat yang telah selesai diserahkan kepada pemegang hak atau kuasanya atau dalam hal tanah wakaf, kepada nadzirnya. Penyerahan sertipikat dapat dilakukan secra bertahap, tidak harus menunggu seluruh target kegiatan selesai. Penyerahan sertipikat dilaksanakan pleh petugas Kantor Pertanahan, dibukukan dan dibuatkan tanda terima.

Penyerahan Sertipikat yang dilakukan oleh Kantor Pertanahan Minahasa Utara kepada masyarakat yang ada di Kabupaten Minahasa Utara yang terdiri dari: 10 Kecamatan masing-masing Kema, Kauditan, Airmadidi, Kalawat, Dimembe, Talawaan, Wori, Likupang Barat, Likupang Timur dan Likupang Selatan dan Sertipikat yang dibagikan sebanyak 1.500 bidang tanah.

\section{Hasil Wawancara dan Observasi Pelaksanaan PTSL Di Desa Kinabuhutan Kecamatan Likupang Barat}

\section{Hasil Wawancara}

1) Pelaksana PTSL

Berdasarkan wawancara dengan pelaksana PTSL sering yang menjadi kendala adalah penyiapan dokumen dari masyarakat, sehingga sering terjadi masalah dengan tanda batas dan bukti kepemilikan yang tidak jelas asal usul tanah tersebut. SDM juga kurang sehingga pekerjaan menjadi terhambat. Hasil wawancara terhadap pelaksana PTSL disajikan pada Tabel 4.

\begin{tabular}{|c|c|c|}
\hline No & Pertanyaan & Kesimpulan \\
\hline A. & \begin{tabular}{l}
\multicolumn{3}{l}{ Apa yang menjadi } \\
kendala dalam \\
pelaksanaan \\
PTSL?
\end{tabular} & $\begin{array}{l}\text { Menurut pendapat dari pelaksana P TSL } \\
\text { Yang menjadi kendala yaitu kurangnya } \\
\text { kesadaran dari masyarakat dalam } \\
\text { menyiapkan dokumen }\end{array}$ \\
\hline B. & $\begin{array}{l}\text { Masalah apa yang } \\
\text { sering ditemukan pada } \\
\text { saat pelaksanaan } \\
\text { kegiatan PTSL? }\end{array}$ & $\begin{array}{l}\text { Menurut pelaksana masalah yang sering } \\
\text { ditemukan pada saat pelaksanaan } \\
\text { kegiatan P TSL yaitu tanda batas dan } \\
\text { kepemilikan }\end{array}$ \\
\hline C. & $\begin{array}{l}\text { Sebagai petugas } \\
\text { apakah anda merasa } \\
\text { mana yang lebih muda } \\
\text { untuk dikerjakan } \\
\text { antara P RONA dan } \\
\text { P TSL? }\end{array}$ & $\begin{array}{l}\text { Semua mengatakan lebih muda } \\
\text { dikerjakan adalah kegiatan PRONA }\end{array}$ \\
\hline D. & $\begin{array}{l}\text { Bagaimana sambutan } \\
\text { masyarakat terhadap } \\
\text { kegiatan P TSL? }\end{array}$ & $\begin{array}{l}\text { Sambutan masyarakat terhadap kegiatan } \\
\text { P TSL yaitu kurang antusias }\end{array}$ \\
\hline E. & $\begin{array}{l}\text { Bagaimana tanggapan } \\
\text { masyarakat terhadap } \\
\text { petugas dari BP N } \\
\text { pada saat memberikan } \\
\text { penyuluhan tentang } \\
\text { kegiatan P TSL? }\end{array}$ & $\begin{array}{l}\text { Tanggapan masyarakat terhadap petugas } \\
\text { BP N pada saat memberikan penyuluhan } \\
\text { tentang P TSL pada umumnya } \\
\text { menyambut dengan baik }\end{array}$ \\
\hline F. & $\begin{array}{l}\text { Jika ditemukan } \\
\text { masalah dalam } \\
\text { lapangan, contohnya } \\
\text { tanah tersebut tidak } \\
\text { boleh dikukur karena } \\
\text { bermasalah, bagaimana }\end{array}$ & $\begin{array}{l}\mathrm{P} \text { ada umumnya diselesaikan deng an } \\
\text { cara mediasi kedua belah pihak yang } \\
\text { bermasalah apakah masalah batas atau } \\
\text { kepemilikan tanah. }\end{array}$ \\
\hline & $\begin{array}{l}\text { anda } \\
\text { menjelaskan? }\end{array}$ & \\
\hline G. & $\begin{array}{l}\text { Menurut anda apakah } \\
\text { kegiatan } \\
\text { P TSL dapat membantu } \\
\text { masyarakat? }\end{array}$ & $\begin{array}{l}\text { Kegiatan P TSL sangat membantu } \\
\text { masyarakat karena dapat memastikan } \\
\text { bidang tanah yang sudah ada sertipikat } \\
\text { terutama sertipikat lama yang belum } \\
\text { terploting sesuai lokasi yang sebenarnya, } \\
\text { dan dapat memastikan seluruh bidang } \\
\text { tanah di suatu desa/ } \\
\text { kelurahan bisa teridentifikasi. }\end{array}$ \\
\hline $\mathrm{H}$ & $\begin{array}{lr}\text { Bagaimana } & \text { anda } \\
\text { memberikan } & \text { alasan } \\
\text { kepada masyarakat } & \text { sudah } \\
\text { yang } & \text { mempunyai sertipikat, } \\
\text { tetapi harus diukur } \\
\text { kembali/ pemetaan } \\
\text { kembali/ } \\
\text { kembali? }\end{array}$ & $\begin{array}{l}\text { - Menurut pelaksana Tanah yang } \\
\text { sudah bersertipikat disarankan untuk } \\
\text { dipetakan dengan menyerahkan } \\
\text { bersertipikat asli/ fotocopy untuk } \\
\text { dicantumkan koordinat- koordinat }\end{array}$ \\
\hline I. & 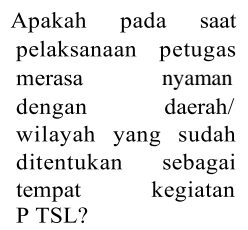 & $\begin{array}{l}\text { - Iya, karena harus tetap dijelankan sesuai } \\
\text { dengan penetapan lokasi }\end{array}$ \\
\hline J. & $\begin{array}{l}\text { Apakah yang menjadi } \\
\text { kelemahan/ } \\
\text { kekurangan dalam } \\
\text { kegiatan PTSL? }\end{array}$ & $\begin{array}{l}\text { Yang menjadi kelemahan P TSL secara } \\
\text { umum kurangnya SDM, dan dalam } \\
\text { pengumpulan data Fisik (P engukuran) } \\
\text { tiap bidang tanah tidak bisa dihadiri oleh } \\
\text { pemilik tanah yang bersangkutan } \\
\text { maupun tetangga yang bersebelahan. }\end{array}$ \\
\hline K.. & $\begin{array}{l}\text { Apa yang menjadi } \\
\text { keuntungan/ kelebihan } \\
\text { dari P TSL? }\end{array}$ & $\begin{array}{l}\text { Yang menjadi keuntungan/Kelebihan } \\
\text { yaitu terdaftarnya bidang- bidang tanah, } \\
\text { dapat terpetakan satu desa/ kelurahan } \\
\text { sehingga bisa didapatkan satu peta desa/ } \\
\text { kelurahan lengkap }\end{array}$ \\
\hline
\end{tabular}

Sumber: Hasil Wawancaraluzahan fenqkap

\section{2) Peserta PTSL}

Berdasarkan wawancara dengan peserta PTSL mengatakan bahwa ada yang berpendapat baik dan sangat baik tentang kegiatan PTSL. Dari beberapa responden mengatakan bahwa kegiatan PTSL menguntungkan dan ada juga 
yang mengatakan sangat menguntungkan karena dengan kegiatan ini masyarakat lebih percaya diri karena sudah memiliki kepastian hukum dan tanda batasnya menjadi jelas, dan juga terdaftarnya bidang- bidang tanah, dapat terpetakan satu desa/ kelurahan sehingga bisa didapatkan satu peta desa/ kelurahan lengkap. Hasil wawancara terhadap peserta PTSL disajikan pada Tabel 5.

\begin{tabular}{|c|c|c|}
\hline No & Pertanyaan & Kesimpulan \\
\hline A. & $\begin{array}{lr}\text { Bagaimana } & \text { pendapat } \\
\text { Bapak/ Ibu } & \text { tentang } \\
\text { kegiatan P TSL? } & \end{array}$ & $\begin{array}{l}19 \text { Responden mengatakan baik, } 2 \\
\text { Responden mengatakan sangat baik }\end{array}$ \\
\hline B. & $\begin{array}{lrr}\text { Apakah pernah } & \text { ada } \\
\text { petugas dari } & \text { BP N yang } \\
\text { datang } & \text { mengadakan } \\
\text { penyuluhan } & \text { tentang } \\
\text { PTSL? } & \end{array}$ & $\begin{array}{l}21 \text { Responden mengatakan Iya (satu } \\
\text { kali) }\end{array}$ \\
\hline C. & $\begin{array}{l}\text { Apakah setelah diadakan } \\
\text { penyuluhan Bapak/ Ibu } \\
\text { mengerti dengan program } \\
\text { P TSL? }\end{array}$ & $\begin{array}{l}1 \text { Responden mengatakan kurang } \\
\text { mengerti, } 2 \text { responden mengatakan } \\
\text { sangat mengerti,18 mengatakan iya } \\
\text { mengerti }\end{array}$ \\
\hline E. & $\begin{array}{l}\text { Apakah tanah yang } \\
\text { dimiliki } \quad \text { Bapak/Ibu } \\
\text { kepunyaan sendiri atau } \\
\text { hanya tanah garapan? }\end{array}$ & $\begin{array}{l}16 \text { Responden mengatakan ada yang } \\
\text { milik sendiri } 5 \text { responden mengatakan } \\
\text { hanya tanah garapan }\end{array}$ \\
\hline F. & $\begin{array}{l}\text { Apakah kegiatan P TSL } \\
\text { sangat menguntungkan } \\
\text { bagi masyarakat? }\end{array}$ & 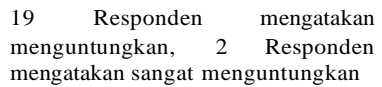 \\
\hline G. & $\begin{array}{lr}\text { Apakah dalam proses } \\
\text { pengurusan } & \text { PTSL } \\
\text { Bapak/Ibu } & \text { menemukan } \\
\text { kesulitan? } & \end{array}$ & $\begin{array}{l}9 \quad \text { Respon mengatakan tidak } \\
\text { menemukan kesulitan, } 12 \text { Responden } \\
\text { mengatakan mempunyai kesulitan } \\
\text { dalam kelengkapan berkas }\end{array}$ \\
\hline $\mathrm{H}$. & $\begin{array}{l}\text { Apakah disekitar } \\
\text { lingkungan Bapak/Ibu } \\
\text { tinggal masih ada tanah- } \\
\text { tanah yang belum } \\
\text { bersertipikat? }\end{array}$ & $\begin{array}{l}21 \text { Responden mengatakan masih ada } \\
\text { tanah- tanah yang belum bersertipikat } \\
\text { disekitar lingkungan }\end{array}$ \\
\hline I. & $\begin{array}{lr}\text { Apakah disaat } \\
\text { pelaksanaan program } \\
\text { P TSL ditemukan masalah } \\
\text { seperti tanah yang } \\
\text { tumpang tindih? }\end{array}$ & $\begin{array}{l}20 \text { Responden mengatakan tidak } \\
\text { ditemukan masalah } \text { dalam } \\
\text { pelaksanaan kegiatan P TSL, } \\
\text { 1 Responden mengatakan masih ada } \\
\text { masalah tapi sudah diperbaiki }\end{array}$ \\
\hline J. & $\begin{array}{l}\text { Menurut Bapak/Ibu mana } \\
\text { yang lebih } \\
\text { menguntungkan P RONA } \\
\text { atau P TSL? }\end{array}$ & $\begin{array}{l}3 \text { Responden mengatakan kedua- } \\
\text { duanya PTSL, P RONA } \\
\text { menguntungkan, 17 Responden } \\
\text { mengatakan P TSL Yang lebih } \\
\text { menguntungkan, }\end{array}$ \\
\hline
\end{tabular}

\section{Hasil Observasi}

1) Penyuluhan dari Kantor Pertanahan Penyuluhan PTSL (Pendaftaran Tanah

Sistematis Lengkap) bersama Kantor Pertanahan Kabupaten Minahasa Utara bertempat di Desa Kinabuhutan, Kecamatan Likupang Barat. Salah satu tujuan diadakannya kegiatan ini tidak lain adalah karena pentingnya kegiatan Pendaftaran Tanah salah satunya adalah untuk menjamin kepastian hukum Hak Atas Tanah masyarakat serta dalam rangka meningkatkan kesejahteraan masyarakat. Pelaksanaan kegiatan penyuluhan dimulai dengan materi mengenai program PTSL yang disampaikan langsung. Dengan diadakannya kegiatan penyuluhan PTSL tersebut kepada masyarakat Desa Kinabuhutan diharapkan akan meningkatkan pemahaman serta kesadaran masyarakat mengenai kegiatan Pendaftaran Tanah. Berdasarkan hasil Observasi dilapangan pelaksanaan Kegiatan PTSL melalui tahapan pertama yaitu Penyuluhan yang dihadiri oleh masyarakat, Pemerintah setempat serta pihak BPN.

2) Pengumpulan Data dilapangan

Pengumpulan data yuridis dilakukan dengan formulir- formulir isian, inventarisasi, identifikasi peserta PTSL dan bersamaan waktunya dengan pemetaan partisipatif yang dilakukan oleh Satgas Fisik. Untuk informasi lebih sampai kepada masyarakat petugas dari BPN mendatangi langsung kepada masyarakat yang ada di lokasi.

3) Pengisian Formulir Permohonan Pemilikan Tanah

Formulir Pengisian Hasil inventarisasi dan identifikasi calon peserta PTSL kemudian diteliti oleh BPN Kabupaten Minahasa Utara dan bagi yang telah memenuhi syarat yang ditentukan selanjutnya ditetapkan menjadi peserta kegiatan PTSL.

4) Pengukuran

Pengukuran bidang tanah yang dilaksanakan dengan menggunakan Peta Dasar Pendaftaran, Data mentah Foto Udara dan Alat Ukur TS (Total Station) dan GPS Geodetik.

5) Pengumuman

Hasil pemeriksaan tanah yang menyimpulkan dapat dibukukan dan atau diterbitkannya Sertipikat Hak Atas Tanah satu bidang tanah diumumkan dalam papan pengumuman selama 14 hari dengan tujuan untuk diketahui khalayak masyarakat dan memberi kesempatan kepada pihak- pihak yang berkepentingan untuk keberatan.

6) Pengolahan Data

Pengolahan data untuk kegiatan PTSL dilakukan di Kantor Pertanahan Kabupaten Minahasa Utara, pengolahan data tersebut melalui aplikasi Komputerisasi Kegiatan Pertanahan (KKP). Mulai dari pendaftaran, proses data sampai pengumuman hasil akhir pengesahan dari Pengumuman. Data Yuridis yang diinventarisasi/ terkumpul dilakukan analisa oleh Panitia Ajudikasi Percepatan, menyangkut data kepemilikan yang 
menunjukan hubungan hukum antara peserta

PTSL dengan tanah obyek PTSL.

7) Penerbitan/Penyelesaian akhir Sertipikat

Setelah pengumuman hasil dari proses data fisik dan yuridis Ketua Panitia Ajudikasi Percepatan menandatangani Surat Keputusan Penetapan Hak dan atau Keputusan/ penegasan/ pengakuan hak. Dalam rangka penerbitan Surat Keputusan Pembrian Hak, bagi para pihak yang mampu membayar BPHTB, bukti pembayaran dibawa pada saat pendaftaran hak. Panitia Ajudikasi Percepatan Bidang Yuridis menyiapkan/ mencetak Sertipikat Hak Atas Tanah, Kepala Kantor Pertanahan menandatangani Sertipikat Hak Atas Tanah atau dapat mendelegasikan kewenangan penandatanganan Sertipikat kepada Ketua Panitia Ajudikasi Pertanahan. Penerbitan/ Penyelesaian akhir Sertipikat dilakukan oleh Petugas BPN.

8) Penyerahan Sertipikat

Setelah Penerbitan Sertipikat Penyerahan Sertipikat dilaksanakan di Kantor Bupati Kabupaten Minhasa Utara. Penyerahan Sertipikat dihadiri oleh penerima Sertipikat.

\section{Upaya BPN dalam Pelaksanaan PRONA dan PTSL Sebagai Tertib Hukum Pertanahan Di Kabupaten Minahasa Utara}

Penyelenggaraan kegiatan PRONA yang diselenggarakan oleh Pemerintah dalam hal ini Kantor Agraria dan Tata Ruang/Badan Pertanahan Nasional Kabupaten Minahsa Utara melakukan upaya pelaksanaan PRONA sebagai upaya tertib hukum pendaftaran tanah. Kegiatan PRONA ini memberikan pelayanan pendaftaran tanah dengan proses yang sederhana, mudah, cepat, dan murah. PRONA merupakan salah satu usaha untuk tercapainya Catur Tertib Pertanahan yang meliputi:

a. Tertib HukumPertanahan

Menurut Keputusan Presiden No. 7 Tahun 1979 ditegaskan5, bahwa yang dimaksud dengan tertib hukum pertanahan adalahdengan tertib hukum pertanahan dimaksudkan bahwa setiap bidang tanah penguasaan, pemilikan dan penggunaannya baik oleh pribadi maupun Badan Hukum mempunyai hubungan hukum yang sah menurut Peraturan Perundangan yang berlaku. Adanya hubungan hukum yang sah tersebut ditunjukan antara lain oleh surat tanda hak atas tanah serta bukti kepemilikan yang sah yakni sertifikat.Tertib Hukum Pertanahan diarahkan pada program:

1) Meningkatkan tingkat kesadaran hukum masyarakat;

2) Melengkapi peraturan perundangan dibidang pertanahan;

3) Menjatuhkan sanksi tegas terhadap pelanggaran yang terjadi;

4) Meningkatkan pengawasan dan koordinasi dalam pelaksanaan hukum agraria.

b. Tertib Administrasi Pertanahan

Dewasa ini, masih terasa adanya keluh kesah dari masyarakat, tentang hal berurusan dengan aparat pertanahan, khususnya dalam hal:

1) Pelayanan urusan yang menyangkut tanah masih berbelit belit dan biaya relatif mahal.

2) Masih terjadi adanya pungutan-pungutan tambahan. Sehingga dengan demikian yang disebut tertib administrasi pertanahan adalah merupakan keadaan dimana :

3) Untuk setiap bidang telah tersedia mengenai aspek-aspek ukuran fisik, penguasaan penggunaan, jenis hak dan kepastian hukumnya yang dikelola dalam sistem Informasi Pertanahan yang lengkap.

4) Terdapat mekanisme prosedur, tata kerja pelayanan di bidang pertanahan yang sederhana, cepat dan massal tetapi menjamin kepastian hukum yang dilaksanakan secara tertib dan konsisten.

5) Penyimpanan warkah-warkah yang berkaitan dengan pemberian hak dan pemanfaatan tanah dilaksanakan secara tertib, beraturan dan terjamin keamanaannya.

c. Tertib PenggunaanTanah

Sampai sekarang masih banyak tanahtanah yang belum diusahakan/dipergunakan sesuai dengan kemampuan dan peruntukkannya, sehingga bertentangan dengan fungsi sosial dari tanah itu sendiri. Demikian yang disebut tertib penggunaan tanah adalah merupakan keadaan dimana:

1) Tanah telah digunakan secara lestari, serasi dan seimbang. Sesuai dengan potensi guna berbagai kegiatan kehidupan dan pengharapan diperlukan untuk 
menunjang terwujudnya tujuan nasional.

2) Penggunaan tanah di daerah perkotaan dapat menciptakan suasana aman, tertib, lancar dan sehat.

3) Tidak terdapat pembentukan kepentingan antara sektor dalam peruntukkan tanah.

d. Tertib Pemeliharaan Tanah dan Lingkungan Hidup

Dewasa ini, banyak sekali orang/badanbadan hukum yang mempunyai atau menguasai tanah yang tidak memperhatikan dan melakukan usaha-usaha untuk mencegah kerusakan-kerusakan dan kehilangan kesuburan tanah. Pada lain pihak, kepadatan penduduk yang melampaui batas tampung wilayah, telah mendorong untuk mempergunakan tanah tanpa mengindahkan batas kemampuan keadaan tanah dan faktor lingkungan hidup.

Unsur-unsur yang berhubungan dengan azas-azas tataguna tanah dan keselamatan hidup sudah benar-benar ditinggalkan guna mengejar kebutuhan hidup yang mendesak dan bersifat sementara. Oleh karena itu, maka yang disebut tertib pemeliharaan tanah dan lingkungan hidup adalah merupakan keadaan dimana:

1) Penanganan bidang pertanahan telah dapat menunjang kelestarian hidup.

2) Pemberian hak atas tanah dan pengarahan penggunaan telah dapat menunjang terwujudnya pembangunan yang berkelanjutan dan bernuansa lingkungan.

3) Semua pihak yang mempunyai hubungan hukum dengan tanah melaksanakan kewajiban sehubungan dengan pemeliharaan tanahtersebut.

Catur Tertib Pertanahan ini merupakan kebijakan bidang pertanahan yang dijadikan "landasan", sekaligus "sasaran" untuk mengadakan penataan kembali penggunaan dan pemilikan tanah serta program-program khusus di bidang agraria untuk usaha meningkatkan kemampuan petani-petani yang tidak bertanah atau mempunyai tanah yang sangat sempit. Badan Pertanahan Nasional bertugas untuk mengelola dan mengembangkan administrasi pertanahan yang meliputi Pengaturan Penggunaan, Penguasaan, Pemilikan dan Pengelolaan Tanah (P4T), penguasaan hak-hak atas tanah, pengukuran dan pendaftaran tanah dan lain-lain yang berkaitan dengan masalah pertanahan, sehingga Badan Pertanahan Nasional sangat berperan aktif dalam mewujudkan penggunaan tanah untuk sebesar-besar kemakmuran rakyat dengan melaksanakan fungsinya di bidang pertanahan sebagai lembaga non Departemen pembantu Presiden.

Perlu diketahui bahwa pendaftaran tanah sangat penting karena kegiatan PRONA dilaksanakan berdasarkan amanah UndangUndang Nomor 5 Tahun 1960 (UUPA).

Pendaftaran tanah merupakan kewajiban Pemerintah dalam hal ini KATR/BPN. Penyelenggaraan PRONA bertujuan untuk menjamin kepastian hukum dan hak atas tanah bagi masyarakat. PRONA merupakan salah satu usaha tercapainya Catur Tertib Pertanahan. Diantara Catur Tertib Pertanahan yaitu PRONA sebagai upaya tertib hukum pertanahan. Dewasa ini banyak sekali terjadi penguasaan pemilikan dan penggunaan tanah oleh orang-orang/badan hukum yang melanggar ketentuan perundangan agraria yang berlaku, karenanya perlu diambil langkah-langkah:

a. Mengadakan penyuluhan/penerangan kepada masyarakat mengenai tertib hukum pertanahan guna tercapainya kepastian hukum yang meliputi penertiban penguasaan dan pemilikan tanah berdasarkan peraturan perundangan Agraria yang berlaku.

b. Dalam pengertian pelaksanaan tertib hukum pertanahan sudah tercakup pelaksanaan tertib dokumentasi dan administrasi tanah. Mengenai sanksi hukum atas pelanggaranpelanggaran yang terjadi.

c. Melengkapi peraturan perundangan di bidang pertanahan.

d. Meningkatkan pengawasan intern di bidang pelaksanaan tugas keagrariaan.

e. Mengambil tindakan tegas terhadap oknum yang sengaja melakukan penyelewengan.

f. Kebersamaan mengadakan interopeksi.

Adanya usaha-usaha tersebut, maka akan terwujud adanya tertib hukum pertanahan yang menimbulkan kepastian hukum pertanahan dan hakhak serta penggunaannya, yang kesemuannya itu akan menciptakan suasana ketentraman dalam masyarakat dan pengayoman masyarakat dari tindakan-tindakan semena-mena serta persengketaan-persengketaan, sehingga mendorong gairah kerja. Berdasarkan Peraturan Kepala Badan Pertanahan Nasional Republik Indonesia Nomor 4 Tahun 2006 Kepala Kantor Wilayah Badan Pertanahan Nasional melaksanakan koordinasi, pembinaan, monitoring 
dan evaluasi secara menyeluruh pelaksanaan Kegiatan PRONA di wilayahnya. Dalam rangka pelaksanaan tugas pokok dan fungsi tersebut, Kepala Kantor Wilayah Badan Pertanahan Nasional dibantu oleh :

a. Kepala Bagian Tata Usaha, yang bertugas memberikan pelayanan administrasi, penyusunan program, dan menyiapkan bahan evaluasi serta penyusunan laporan berkaitan dengan pelaksanaan Kegiatan PRONA;

b. Kepala Bidang Survei, Pengukuran, dan Pemetaan yang bertugas melakukan koordinasi, bimbingan teknis dan pengawasan pelaksanaan pengukuran, pemetaan dalam rangka pelaksanaan Kegiatan PRONA;

c. Kepala Bidang Hak Tanah dan Pendaftaran Tanah yang bertugas melakukan koordinasi, bimbingan teknis dan pengawasan pelaksanaan penegasan konversi atau pengakuan hak, pemberian hak atas tanah, pembukuan dan penerbitan sertifikat dalam rangka pelaksanaan Kegiatan PRONA;

d. Kepala Bidang Pengaturan dan Penataan Pertanahan yang bertugas melakukan koordinasi, bimbingan teknis dan pengawasan berkaitan dengan pelaksanaan Kegiatan PRONA di atas Tanah Obyek Landreform (TOL) atau Obyek IP4T;

e. Kepala Bidang Pengkajian dan Penanganan Sengketa dan Konflik Pertanahan yang bertugas melakukan koordinasi, bimbingan teknis dan pengawasan dalam rangka penanganan dan penyelesaian sengketa, konflik dan perkara pertanahan pada lokasi Kegiatan PRONA;

f. Kepala Bidang Pengendalian Pertanahan dan Pemberdayaan masyarakat yang bertugas melakukan koordinasi, bimbingan teknis dan pengawasan pelaksanaan PRONA.

Di dalam pelaksanaan operasional di lapangan masih sering dijumpai Peserta Kegiatan PRONA menghadapi kendala dan masalah dalam hal pemenuhan kelengkapan dokumen pembuktian penguasaan dan kepemilikan tanah sehingga memperlambat pencapaian target tepat waktu. Terhadap dokumen pembuktian penguasaan dan kepemilikan tanah diminta kepada Kepala Kantor Wilayah, Kepala Kantor Pertanahan dan para Koordinator serta para Pelaksana Kegiatan PRONA untuk berpedoman pada Peraturan Pemerintah Nomor 24 Tahun 1997, Peraturan Menteri Negara Agraria/Kepala Badan Pertanahan Nasional Nomor 3 Tahun 1997,
Peraturan Menteri Negara Agraria/Kepala Badan Pertanahan Nasional Nomor 9 Tahun 1999 dan Peraturan Menteri Negara Agraria/Kepala Badan Pertanahan Nasional Nomor 1 Tahun 2010 serta ketentuan peraturan lainnya yang terkait.

Kendala lain dalam pelaksanaan kegiatan PRONA di Kabupaten Gunungkidul adalah pemilik tanah tidak berada di tempat, hal seperti itu banyak dijumpai karena banyak dari pemilik tanah yang tinggal di luar kota, sehingga menyulitkan petugas dalam pendataan. Keberadaan pemilik tanah sangat penting karena dalam pedataan peserta kegiatan PRONA ini banyak syarat-syarat yang harus dipenuhi oleh peserta.

\section{Pembahasan}

Undang-Undang Pokok Agraria dengan seperangkat peraturan pelaksanaannya bertujuan untuk terwujudnya jaminan kepastian hukum terhadap hak-hak atas tanah di seluruh wilayah Indonesia. Jika dihubungkan dengan usaha-usaha pemerintah dalam rangka penataan kembali penggunaan penguasaan dan pemilikan tanah, maka pendaftaran hak atas tanah adalah merupakan suatu sarana penting untuk terwujudnya kepatian hukum. Dalam pasal 19 ayat (1) Undang-Undang Nomor 5 Tahun 1960 disebutkan bahwa, "Untuk menjamin kepastian hukum oleh pemerintah diadakan pendaftaran tanah di seluruh wilayah Republik Indonesia menurut ketentuan yang diatur dengan peraturan pemerintah". Ketentuan tersebut merupakan ketentuan yang ditujukan kepada pemerintah untuk menyelenggarakan pendaftaran tanah di seluruh wilayah Indonesia. Para pemegang hakhak atas tanah yang bersangkutan harus mendaftarkan tanahnya masing-masing dalam rangka memperoleh surat tanda bukti hak atas tanah yang berlaku sebagai alat pembuktian yang kuat pemegangan hak atas tanah (Bachtiar Effendy, 1993).

Berdasarkan ketentuan tersebut, tujuan pendaftaran tanah adalah memberikan kepastian hukum dan perlindungan hukum kepada pemegang hak atas tanah. Pemegang hak atas tanah diberikan sertipikat hak atas tanah. Sertipikat hak atas tanah dapat digunakan sebagai alat bukti yang kuat dalam membuktikan bahwa pemegang sertifikat adalah pemilik tanah yang tercantum dalam sertifikat. Pemerintah melalui Badan Pertanahan Nasional dalam rangka melaksanakan kebijakan di bidang pertanahan 
senantiasa berupaya untuk membina dan mengembangkan kegiatan- kegiatan penyelenggaraan pengelolaan administrasi pertanahan, termasuk di dalamnya meliputi pendaftaran tanah secara konseptional dan terpadu serta program lainnya yang dilaksanakan oleh pemerintah.

Dalam visi dan misi BPN yaitu menjadi lembaga / kantor pertanahan yang mampu mewujudkan tanah dan pertanahan untuk sebesarbesar kemakmuran rakyat, serta keadilan dan berkelanjutan sistem kemasyarakatan, kebangsaan dan kenegaraan Republik Indonesia, Mengembangkan dan menyelenggarakan politik dan kebijakan pertanahan untuk meningkatkan kesejahteraan rakyat, peningkatan tatanan kehidupan yang lebih berkeadilan yang kaitannya dengan Penguasaan, Pemilikan, Penggunaan, dan Pemanfaatan Tanah (P4T), perwujudan tatanan kehidupan yang harmonis dengan mengatasi berbagi konflik dan perkara pertanahan.

Kantor pertanahan Kabupaten Minahasa Utara berupaya untuk melaksanakan kebijakan administrasi pertanahan dalam rangka terciptanya kepastian hukum bagi pemegang hak atas tanah juga untuk terlaksananya catur tertib pertanahan maka berdasarkan Keputusan Menteri Dalam Negeri Nomor 220 Tahun 1981 tentang Proyek Operasional Agraria diadakan program Proyek Operasional Nasional Agraria di Kabupaten Minahasa Utara antara lain di Desa Kinabuhutan Kecamatan Kecamatan Likupang Barat. Juga adanya Peraturan Menteri Negara Agraria/Kepala Badan Pertanahan Nasional Nomor 35 Tahun 2016 tentang percepatan pelaksanaan Pendaftaran Tanah Sistematis Lengkap (PTSL).

\section{a. Pelaksanaan Program Agraria (PRONA)}

Dalam pelasaksanaan PRONA pihak pelaksana telah mengikuti sesuai dengan tahapan pelaksana PRONA meliputi: (a) Penetapan Lokasi, (b) penyuluhan, (c) pengumpulan data/ alat bukti/ alas hak, (d) pengukuran bidang tanah (e) pemeriksaan tanah (f) pengumuman, (g) penerbitan/ penyelesian akhir sertipikat, (h) penyerahan akhir sertipikat, (i) penyerahan sertipikat. Dalam pelaksanaan PRONA yang menjadi kendala dalam pelaksanaannya yaitu kurang siapnya masyarakat terhadap bukti kepemilikan (alas hak) serta ketidakpahaman masyarakat akan kelengkapan berkas. Walaupun demikian dalam pelaksanaannya masyarakat sangat menyambut dengan baik pelaksanaan PRONA tersebut. Sekitar 70\% masyarakat mengatakan sangat baik petugas BPN Kabupaten Minahasa Utara dalam melakukan penyuluhan, dan $30 \%$ masyarakat mengatakan cukup baik.

Peserta PRONA, mengatakan bahwa kegiatan PRONA relative baik dari 23 responden, 3 responden mengatakan sangat baik, 16 responden mengatakan baik dan 4 cukup baik. Penyuluhan yang dilakukan oleh pelaksana menurut peserta PRONA juga sudah cukup baik, dimana dari 23 responden 20 responden mengatakan mengerti dengan program PRONA dan 3 responden mengatakan kurang mengerti dengan program PRONA. Masalah bagi peserta di Desa Kinabuhutan terutama menyangkut kepemilikan tanah, 13 responden mengatakan sering menimbulkan kesulitan, terjadi tumpang tindih, 10 responden mengatakan tidak menemukan kesulitan. Juga dikemukakan oleh peserta PRONA tentang kelengkapan berkas, 11 responden menunjukkan kelengkapan berkas dan 12 responden mengalami masalah dalam mempersiapkan kelengkapan berkas. Didalam pelaksanaannya ke 12 responden tersebut dibimbing oleh petugas/ pelaksana program PRONA dalam melengkapi berkas tersebut. Kekurangan masyarakat peserta program PRONA pada dasarnya adalah menyiapkan bukti kepemilikan tanah seperti surat surat kepemilikan tanah, riwayat tanah dari pemegang hak pertama sampai pemilik terakhir) misalnya bukti kepemilikan berdasarkan jual beli, hibah atau warisan. Juga kekurangan pada tanda tanda batas atas tanah mereka.

b. Percepatan Pendaftaran Tanah Sistematis Lengkap (PTSL)

Dalam rangka mewujudkan kehadiran Negara dibidang Pertanahan dengan memberikan jaminan kepastian hukum hak atas tanah sebagai bukti hak kepemilikan sebagaimana diamanatkan dalam pasal 19 Undang- undang Nomor 5 Tahun 1960 tentang Peraturan Dasar Pokok- pokok Agraria, pemerintah berkewajiban menyelenggarakan pendaftaran tanah diseluruh wilayah Republik Indonesia. Oleh karena itu dirasa perlu untuk dilakukan percepatan pendaftaran taah untuk mengejar 
presentase tanah terdaftar yang masih dibawah 50\% hingga saat ini. Salah satu cara yang ditempuh Kementerian Agraria dan Tata Ruang adalah melalui program percepatan pelaksanaan pndaftaran tanah sistematis lengkap sebagaimana diatur diatur dalam Peraturan Menteri Agraria dan Tata Ruang/ Badan Pertanahan Nasional Nomor 35 Tahun 2016 Tentang percepatan Pelaksanaan Pendaftaran Tanah Sistematis Lengkap.

PTSL adalah kegiatan pendaftaran tanah untuk pertama kali (baik pendaftaran tanah pertama kali konversi/ atau pengakuan/ penegasan mhak ataupun pendaftaran tanah pertama kali (pemberian hak) yang dilakukan secara SERENTAK yang meliputi semua obyek pendaftaran tanah yang belum didaftar dalam suatu wilayah desa/ kelurahan atau nama lainnya setingkat dengan itu, meliputi tahapan sebagai berikut: (a) Penetapan lokasi, (b) Penyuluhan, (c) Pengumpulan Data Yuridis, (d) Pengukuran bidang tanah, (e) Pengolahan Data Yuridis dan Pembuktian Hak (f) Pemeriksaan Tanah (g) Pengumuman, (f) Pengesahan/ Hasil Pengumuman yang disahkan dalam Berita Acara Hasil Pengumuman oleh Panitia, (g) Pembukuan hak dan Pencetakan buku Tanah, (h) Penyerahan Sertipikat (i) Pengolahan Warkah/ Dokumen (j)Pelaporan.

Berdasarkan hasil wawancara pelaksana PTSL menyatakan bahwa ketidaksiapan masyarakat dalam menyiapkan dokumen kepemilikan tanah dan tanda batas sering menjadi kendala dalam pengurusan pendaftaran tanah sistematis lengkap. Diakibatkan oleh kurangnya pengetahuan masyarakat tentang pelaksanaaan PTSL termasuk pengurusan kelengkapan berkas pemilikan dan batas tanah menyebabkan masyarakat kurang antusias. Dalam pelaksanaan PTSL walaupun tanah sudah bersertifikat disarankan untuk dipetakan. Dari hasil wawancara didapatkan bahwa masih ada tanah tanah yang belum bersertifikat disekitar mereka sehingga dianjurkan untuk dipetakan untuk mempermudah pengurusan selanjutnya.

Hasil wawancara dengan masyarakat 21 peserta PTSL, 18 peserta menyatakan mengerti tentang pelaksanaan PTSL pada waktu dilakukan penyuluhan oleh BPN Kabupaten Minahasa Utara dan 2 peserta menyatakan kurang mengerti. Pada dasarnya masyarakat peserta PTSL menyatakan bahwa pengsertifikan tanah melalui program PTSL sangat baik hanya saja yang menjadi kendala adalah penyiapan dokumen kepemilikan tanah dan tanda batas seperti yang telah diuraikan diatas. Dari 21 peserta program PTSL, 9 responden menyatakan tidak menemukan kesulitan dalam melengkapi kelengkapan berkas tanah dan 12 responden mengatakan mempunyai kesulitan dalam menyiapkan kelengkapan berkas kepemilikan tanah terutama hal ini ada hubungannya dengan status/kepemilikan tanah.

Peserta program PTSL sebanyak 21 orang, 12 responden menyatakan kesulitan dalam kelengkapan berkas tanah dan 9 responden menyatakan tidak menemukan kesulitan. Kekurangan masyarakat peserta program PTSL yang ditemui pelaksana dilapang terutama adalah bukti kepemilikan tanah yang kurang jelas; pada saat pengukuran pemilik tanah tidak berada ditempat, serta tanda tanda batas yang juga kurang jelas.

Berdasarkan Peraturan Menteri Agraria dan Tata Ruang Nomor 35 Tahun 2016 tentang Percepatan Pelaksanaan Pendaftaran Tanah Sistematis Lengkap (PTSL), semua tanah bisa didaftar untuk sertifikasi, tak terkecuali bidang tanah yang statusnya masih dalam sengketa. Semua bidang tanah yang masuk program PTSL akan disertifikat tentunya setelah stastusnya sudah jelas. Manfaat metode/ program PTSL adalah pihak BPN daerah yang bersangkutan akan memiliki catatan mengenai luas bidang tanah dalam suatu daerah dan semua bidang tanah tersebut akan terpetakan.

\section{Kesimpulan}

Berdasarkan hasil penelitian dan pembahasan yang telah diuraikan diatas, penulis menarik kesimpulan bahwa:

1. Pelaksanaan pensertipikatan tanah melalui program PRONA di Desa Kinabuhutan Kecamatan Likupang Barat Kabupaten Minahasa Utara sudah berjalan sesuai dengan tahapan kegiatan, yang menjadi masalah dalam pelaksanaannya adalah bukti kepemilikan (alas hak) selain itu yang menjadi masalah juga adalah mengenai 
kepemilikan dalam arti hanya menguasai fisik atau sebagai penggarap yang menyebabkan sulit untuk mengetahui riwayat tanah yang menjadi syarat utama dalam kepengurusan sertipikat. Kekurangan masyarakat peserta program PRONA dalam menyiapkan bukti kepemilikan tanah seperti surat- surat kepemilikan tanah, riwayat tanah dari pemegang hak pertama sampai pemilik terakhir seperti bukti kepemilikan berdasarkan jual beli, hibah atau warisan. Juga kekurangan pada tanda tanda batas atas tanah mereka.

2. Pelaksanaan program pengsertifikatan tanah melalui program PTSL di Desa Kinabuhutan Kecamatan Likupang Barat Kabupaten Minahasa Utara juga sudah sesuai dengan tahapan. Kekurangan masyarakat peserta program PTSL yang ditemui pelaksana dilapang terutama adalah bukti kepemilikan tanah yang kurang jelas; pada saat pengukuran pemilik tanah tidak berada ditempat, serta tanda tanda batas yang juga kurang jelas.

\section{Saran}

Saran-saran yang dapat diberikan dari hasil penelitian ini adalah:

1. Salah satu penunjang pelaksanaan program PRONA maupun PTSL pihak BPN Kabupaten Minahasa Utara yaitu dengan menambah tenaga SDM yang ada terutama untuk tenaga pengukuran di lapang.

2. Hambatan yang berhubungan dengan pemilik tanah tidak atau belum memasang tanda atau patok batas tanahnya disarankan pemasangan patok dilakukan dilapangan disaksikan tetangga batasnya.

3. Pendaftaran tanah secara sistematik perlu dilaksanakan secara terus menerus dan berkesinambungan terhadap seluruh bidang tanah yang ada di desa/kelurahan secara lengkap untuk terciptanya tertib pertanahan di seluruh wilayah Republik Indonesia.

4. Pelaksaanaan pendaftaran tanah sistematik tidak hanya bergantung kepada pemerintah, melainkan diarahkan kepada pendidikan masyarakat melalui ajudikasi swadaya dan swadana demi terwujudnya masyarakat yang mandiri dalam proses pelaksaanaan pendaftaran tanah.

\section{DAFTAR PUSTAKA}

Harsono B., 2008. Hukum Agraria Indonesia Himpunan Peraturan Peraturan Hukum Tanah.

Manado Post., 2018. 10 Ribu Lahan Target PTSL Tahun Ini. Manado.

Mantjoro, E. 1997. Sejarah penduduk dan lingkungan hidup Desa Talise. Konsuttan sosio-ekonomi. Proyek Pengelolaan Sumberdaya Wilayah Pesisir, Universitas Sam Ratulangi, Manado.

Peraturan Pemerintah Nomor 24 Tahun 1997 tentang Pendaftaran Tanah.

Peraturan Menteri No. 35 Tahun 2016. Program Pelaksanaan Pendaftaran Sistematis secara Lengkap (PTSL).

Peraturan Presiden RI Nomor 17 Tahun 2017. Tentang ketentuan Agraria Tata Ruang.

Peraturan Pemerintah RI Nomor 24 Tahun 1997. Tentang Pendaftaran Tanah.

Soerodjo I., 2002. Kepastian Hukum Pendaftaran Hak Atas Tanah di Indonesia. Arloka, Surabaya

Sumarja, F. X. 2012. Problematika Kepemilikan Tanah Bagi Orang Asing, Indepth Publising, Bandar Lampung.

Undang-Undang Dasar Tahun 1945

Undang-Undang Republik Indonesia Nomor 5 Tahun 1960 tentang Peraturan Dasar PokokPokok Agraria di dalam Pasal 19

Undang-Undang Nomor 5 Tahun 1960 tentang Peraturan Dasar Pokok-Pokok Agraria (UUPA). 